Article

\title{
Component-Based Model for Building Material Stock and Waste-Flow Characterization: A Case in the Île-de-France Region
}

\author{
Rafaela Tirado ${ }^{1,2, *}{ }^{\mathbb{D}}$, Adélaïde Aublet ${ }^{1}$, Sylvain Laurenceau ${ }^{1}$, Mathieu Thorel ${ }^{1}{ }^{(\mathbb{D}}$, Mathilde Louërat ${ }^{1}$ \\ and Guillaume Habert ${ }^{2}$ (D) \\ 1 Scientific and Technical Centre for Buildings (CSTB), University Paris-Est, 24 Rue Joseph Fourier, \\ 38400 Saint-Martin-d'Hères, France; Adelaide.AUBLET@cstb.fr (A.A.); Sylvain.LAURENCEAU@cstb.fr (S.L.); \\ Mathieu.THOREL@cstb.fr (M.T.); Mathilde.LOUERAT@cstb.fr (M.L.) \\ 2 Sustainable Construction Department, IBI, ETH Zurich, Stefano-Franscini-Platz 5, 8093 Zürich, Switzerland; \\ habert@ibi.baug.ethz.ch \\ * Correspondence: tdeanira@student.ethz.ch
}

Citation: Tirado, R.; Aublet, A.; Laurenceau, S.; Thorel, M.; Louërat, M.; Habert, G. Component-Based Model for Building Material Stock and Waste-Flow Characterization: A Case in the Île-de-France

Region. Sustainability 2021, 13, 13159. https://doi.org/10.3390/su132313159

Academic Editor: Cinzia Buratti

Received: 5 October 2021

Accepted: 23 November 2021

Published: 27 November 2021

Publisher's Note: MDPI stays neutral with regard to jurisdictional claims in published maps and institutional affiliations.

Copyright: (c) 2021 by the authors. Licensee MDPI, Basel, Switzerland. This article is an open access article distributed under the terms and conditions of the Creative Commons Attribution (CC BY) license (https:// creativecommons.org/licenses/by/ $4.0 /)$.

\begin{abstract}
Building demolition is one of the main sources of waste generation in urban areas and is a growing problem for cities due to the generated environmental impacts. To promote high levels of circular economy, it is necessary to better understand the waste-flow composition; nevertheless, material flow studies typically focus on low levels of detail. This article presents a model based on a bottom-up macro-component approach, which allows the multiscale characterization of construction materials and the estimation of demolition waste flows, a model that we call the BTP-flux model. Data mining, analytical techniques, and geographic information system (GIS) tools were used to assess different datasets available at the national level and develop a common database for French buildings: BDNB. Generic information for buildings in the BDNB is then enriched by coupling every building with a catalog of macro-components (TyPy), thus allowing the building's physical description. Subsequently, stock and demolition flows are calculated by aggregation and classified into 32 waste categories. The BTP-flux model was applied in Île-de-France in a sample of 101,320 buildings for residential and non-residential uses, representative of the assessed population (1,968,242 buildings). In the case of Île-de-France, the building stock and the total demolition flows were estimated at 1382 Mt and $4065 \mathrm{kt}$, respectively. For its inter-regional areas-departments-, stock and demolition waste can vary between 85 and 138 tons/cap and 0.263 and 0.486 tons/cap/year, respectively. The mean of the total demolition wastes was estimated at 0.33 tons/cap/year for the region. Results could encourage scientists, planners, and stakeholders to develop pathways towards a circular economy in the construction sector by implementing strategies for better management of waste recovery and reintegrating in economic circuits, while preserving a maximum of their added value.
\end{abstract}

Keywords: building-stock modeling; material-flow analysis (MFA); bottom-up; component-based; circular economy; urban metabolism

\section{Introduction}

Currently, $55 \%$ of the world population lives in urban areas, and urbanization will increase rapidly to $68 \%$ by 2050 [1]. This growth translates into the creation of new towns and the densification and expansion of existing ones. Consequently, this increases the consumption of building materials and the production of construction and demolition wastes (CDW). Cities already consume $75 \%$ of natural resources [2]. While a significant amount of materials consumed for construction and renovation remain stored in the built stock (buildings and infrastructure) for a relatively long service life [3], another significant part of these materials will be part of the CDW flows associated with the built stock dynamic [4-6]. Cities produce $50 \%$ of global waste [2]. Globally, the percent of 
CDW by country going to landfill sites is strongly variable; for instance, $25 \%, 26 \%, 27 \%$, $30 \%$, and $40 \%$ of the CDW is landfilled in Hong Kong, France, Canada, USA, and Brazil, respectively [7,8], and details of landfilled CDW for the EU are given by [9]. This landfilled CDW represents a threat for the environment [10-12]. More sustainable management of CDW is necessary, yet CDW management is complex and still represents a challenge [11].

Faced with these observations, several cities and countries set targets to reduce the consumption of raw materials and minimize waste production [13]. Internationally, G7 member states founded the Resource Efficiency Alliance to protect and improve resource efficiency [14]. In France, the Anti-Waste Circular Economic law (AGEC) established new measures to preserve natural resources, reduce environmental impacts, improve the treatment and management of waste, and transition from a linear economy to a circular economy (CE) [15].

Research and developments to support the emergence of the CE have been prolific in the past decade [16]. Among the developments, material-flow analysis (MFA) is recognized as an essential method for the definition of CE strategies [17-19]. Applied to building stocks, MFA is an optimal tool to comprehensively assess material flows and stocks and their potentials for waste value recovery $[20,21]$. Spatiotemporal characterization of buildings stocks provides stakeholders and policymakers with comprehensive knowledge of the composition and amount of construction materials and waste flows, enabling them to anticipate related environmental issues and act in consequence [22,23]. For instance, for waste management, MFA results can be used to estimate the provision of sites for storage, treatment, and valorization of waste for their reintegration into the economic loop [24].

In this article, we present a component-based model of MFA, called the BTP-flux model. The BTP-flux model assesses material stocks and flows in residential (individual housing and collective housing) and non-residential buildings (industrial, office, and education); the aim of the assessment is to identify characteristics of the urban mine at different scales to anticipate CWD flows and plan for optimal resource management. More specifically, three research question are addressed: (i) what are the characteristics of the stock in terms of material composition, building use, and building age?; (ii) what is the nature and the quantity of material stocks and flows, by waste categories, presented and generated at different scales in the territory?; and (iii) what is the relation between the stock and the urban characteristics of the assessed territories? The BTP-flux model was applied in the Île-de-France region in France and focused on deconstruction flows.

\subsection{State of the Art}

MFA, linked to geographic information systems (GISs), has become a powerful tool for analyzing and interpreting material building stocks and CDW flows to formulate, for instance, CE strategies.

Several reviews overview the variety of approaches developed for material stock assessment (MSA) and MFA in the built stock [4,6,25-28]. The main approaches are bottomup, top-down, or a combination of both. In practice, urban metabolism assessments are carried at temporal, spatial, and administrative scales where sufficient data are available and accessible [29]. Given that data availability and coverage varies from one territory to another, there is no standard approach; on the other hand, the approaches can complement each other or be structured to evolve.

Bottom-up approaches offer more flexibility in the description and analysis of stocks and material flows [18,27]. Indeed, bottom-up approaches provide a detailed description of buildings' materials and a better spatial differentiation [30]. Moreover, when combined with GIS, MFA approaches, whether bottom-up or top-down, allow the spatial characterization of stocks and waste for a given geographical area [25,31-36], making MFA even more useful for decision making and planning.

So, in terms of accuracy and details, a fully bottom-up material characterization at the building scale is ideal for identifying the nature, quantity, and state of resources to increase their circularity on a given territory. However, such modeling is not possible at territorial 
scale because it requires significant economic investment and time to collect data [27,31]. To overcome this setback, various authors developed archetypes associated with material intensity coefficients (MICs), and substantial efforts have been made to collect, organize, and harmonize MICs in databases [37-39]. In such models, MICs are then multiplied by the floor area or the total volume of given building segments at the territory scale to obtain the material stocks or flows $[3,21,32,38,40-46]$. Although these models can help to obtain rough estimations of material quantities at territorial scale, they are not suited to draw and support specific conclusions in the definition of territorial strategies for CE. Indeed, MICs are, in most cases, not detailed enough-often materials are grouped into large categories (e.g., inert, non-hazardous, and hazardous) or only a few material categories are studied (e.g., metals), neither representative enough of building stock diversity. Given that, few archetypes are used to represent entire territories and using MICs intrinsically neglects the influence of geometric parameters, such as building compacity, on material quantities [47-50].

On the opposite side, more detailed building-by-building approaches [51] make the most out of available information at the scale of individual buildings and can consequently offer more accurate results. In addition, models that use this kind of approach are often easier to maintain and update as the information is available at a more refined level (e.g., product scale). Indeed, product-scale knowledge can be more easily updated, thanks to specific studies compared to a longer knowledge cycle when information is aggregated at a building or higher level.

Notably, the digital representation of the physical and functional characteristics of building elements with building information modeling (BIM) tools gives birth to initiatives to better manage materials in the built stock; nevertheless, they are mainly oriented towards new construction because their implementation in the existing stock is still limited due to several factors, such as data availability, modeling, and uncertainties [52]. However, various BIM initiatives have emerged to improve knowledge of materials in the building stock [53,54], and estimate and manage CDWs [55-57].

These statements can be applied to the model and its application to the Île-de-France region presented in this article. Indeed, previous studies based on MICs already estimated construction materials and waste flows for the capital region of France [58-61]. Yet, the model presented in this article - the BTP-flux model—goes further and offers a buildingby-building approach with a description of building elements (e.g., exterior walls, roof) based on the intensive use of available data, such as the Energy Performance Diagnosis (EPD) database.

In addition, the BTP-flux model aims to tackle most of the shortcomings of current research reported in recent reviews [4,27]:

- First, it can be applied to both residential and non-residential buildings.

- Second, the results are broken down by waste categories and not just by large groups (for instance: inert, hazardous, and non-hazardous wastes).

- Third, the structure of the model allows its replicability to other territories in France.

- Finally, the model can be easily updated (because it is based on a rich macro-component description of buildings) to allow its continuous improvement.

\subsection{Objectives}

The BTP-flux model presented in this article aims to advance building-stock modeling from a pure archetype technique towards a building-by-building technique [62] by the intensive use of a geospatial database. The operational objectives of this model are three-fold:

- Measure: estimate, both nature and quantity, of the building stock and construction waste generated by the deconstruction and renovation of buildings, its territorial distribution, the distribution of waste in the various outlets, and the associated treatment costs;

- Optimize: anticipate the production of waste to limit and valorize it as well as possible; 
- Develop new channels: determine the volumes and categories of waste generated by territory to support actors of building waste management in the development of new channels of reuse or recycling.

The Île-de-France region (France) building stock was selected as a case study to test the model. However, this model can be applied in any other French territory or any territories with similar available data.

\section{Materials and Methods}

\subsection{Methodology Overview}

The BTP-flux model is built in a modular fashion and is based on several data and software bricks developed by the Scientific and Technical Centre for Buildings (CSTB). Each element performs a particular function or set of coherent functions and can be assembled in various configurations to produce more complex software solutions for different uses and needs. The four main elements of the BTP-flux model are:

- The French national building database (BDNB): a data product built by joining multiple national building-stock databases, including property taxes, energy performance diagnostics, and energy consumption. The BDNB comprises more than 20 million localized buildings' geometry with multiple thematic layers, such as wall and roof material, energy performance, and energy consumption at the scale of single buildings.

- TyPy: a database and management tool for building typologies and components and their assemblies as macro-components. Material properties are linked to product EPD to assess nature and quantities of construction products within a given building.

- The geometric service: a software brick that calculates a building's geometric properties from its geospatial data. Namely, this service provides the area, perimeter, and azimuth of each surface of the building envelope.

- The BTP-flux model itself provides the following functions, in addition to orchestrating the call to the various elements mentioned above: the estimation of renovation and demolition waste on a territorial scale, the assessment of the outlets and costs associated with the management of each waste and potential secondary resources, and the extrapolation of results calculated for a sample of the target population, namely the entire building stock of a territory.

Figure 1 focuses on the sequence of operations executed to perform the material-flow analysis at a territorial scale. This sequence can be described in five steps: (1) data merging and sample generation (Section 2.2.1), (2) data enrichment (Section 2.2.2), (3) modeling: sizing and material accounting (Section 2.2.3), (4) flow assessment (Section 2.2.4), and (5) extrapolation (Section 2.2.5). The entire model was implemented in Python.

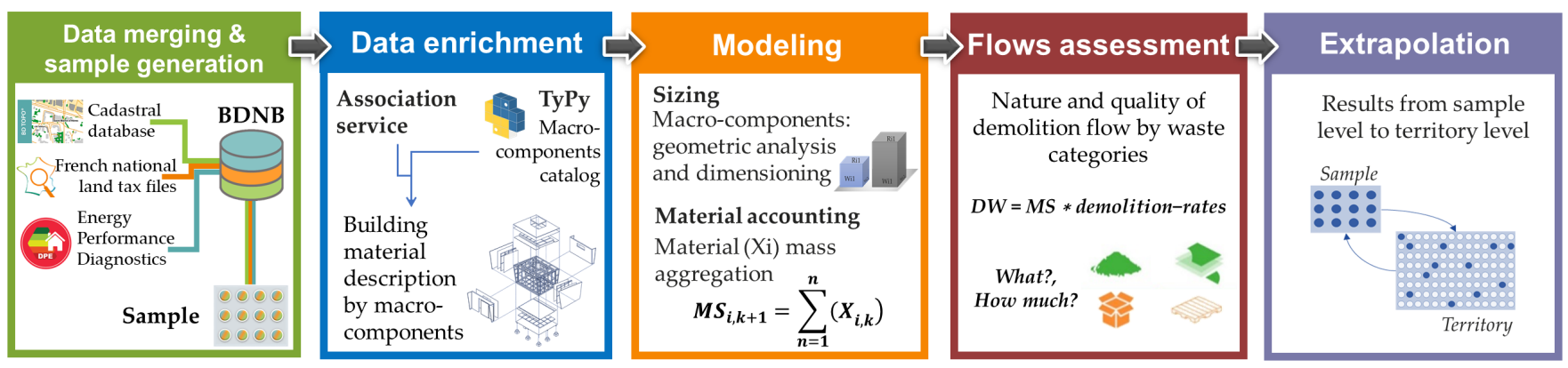

Figure 1. Schematic structure of the bottom-up macro-component-based BTP-flux model.

\subsection{BTP-Flux Model}

2.2.1. Data Merging and Sample Generation

(1) Available Data Description and Data Requirements 
The open-source GIS databases have continually improved in recent years due to the active and collaborative participation of governments and stakeholders from the research sector, industry, and other interested organizations. Reliable GIS data offers the possibility, for instance, to better understand the distribution of material stocks in cities and the expansion or change of built-up land; therefore, these data can allow the deployment of more reactive and coherent urban planning strategies and also optimize resources and waste management, and consequently, mitigate environmental impacts and improve urban life quality.

In France, various databases provide the input and enrichment information required for building modeling. Three sources of raw data are used to characterize the building stock at the territorial scale: the French national land tax files (fichiers fonciers from CEREMA) [63], the cadastral database (BD-TOPO ${ }^{\circledR}$ from the National Institute of Geographic and Forest Information (IGN)) [64], and the Energy Performance Diagnosis (EPD) of buildings database (DPE from ADEME) [65]. Each is a construction-related national public database and provides specific pieces of information merged at a different scale.

Fichiers fonciers, yearly updated and theoretically exhaustive, brings information, such as cadastral parcel geometries (that contain targeted buildings) and numerous nongeometrical data at the building scale: construction year, number of stories, main structural materials for walls and roofs, final use of the buildings, complete postal addresses, floor areas, and number of rooms. Material descriptions tend to be less captured for recent decades, but other data are trustable. The BD-TOPO, also theoretically exhaustive and up to date, gives geometric information, such as building footprint and height. The EPD database gathers more than 9 million building diagnoses (a mix of full constructions and flats) for more than 32 million dwellings in France. Each EPD provides information on the energy consumption classes, the greenhouse gas (GHG) emissions class, the intermediate thermal calculation variables, but also information, for example, on the materiality and performance of the walls, floors, glass surfaces, and systems; and, a postal address. This information is present principally at the dwelling level.

(2) Data Processing (Data Merging: Geo- and Not Geo-Processing)

Merging the databases is essential because, as mentioned above, the databases' information is not on the same scale (plot, building, and unit tax places; building; and housing for cadastral, land, and EPD data, respectively). Therefore, the main objective of this step was to have a centralized database with consistent data; that is to say, to develop a database with a single entity, the building, that could contain the entire entity's characteristics information and that it be precise and accurate. Merging the data geographically also makes it easy to update the database when new data becomes available or when it is updated.

Data merging follows two sequential steps: (1) a geometric allocation of BD-TOPO building geometries with fichiers fonciers tabular data at the cadastral parcel scale and (2) a merging of the resulting dataset with EPD, thanks to postal addresses (previously geocoded with the French National Addressed Database (API: https:/ / geo.api.gouv.fr / adresse, accessed on 17 June 2020)).

For the first data-merging step (fichiers fonciers and BD-TOPO), we classified cadastral parcels into four categories:

- Cardinality 1-1: one building entry in fichiers fonciers and one building footprint in BD-TOPO exist on the parcel geometry. No ambiguity exists on the geometric matching. This configuration mainly gathered detached individual housing and collective housing in the city center where parcel boundaries meet building footprint boundaries.

- Cardinality 1-n: one building entry in fichiers fonciers and $\mathrm{n}$ building footprints in BD-TOPO exist on the parcel geometry. Here, if building uses are only residential, we made geometrical clusters and took the biggest one as the building footprint. The building height retained from BD-TOPO is the maximal height of the buildings of this cluster. Otherwise (i.e., non-residential use), we created a collection of geometries 
and assigned one to the single entry in fichiers fonciers. This configuration frequently gathered residential buildings with detached dependencies on the same parcel.

- Cardinality $n-1: n$ building entries in fichiers fonciers and one building footprint in BD-TOPO exist on the parcel geometry. No specific treatment was taken; we took the weighted sums of each fichiers fonciers entry feature to characterize the building. This configuration gathered physical collective housing buildings that are generally split into stairwell units.

- Cardinality $\mathrm{n}-\mathrm{m}: \mathrm{n}$ building entries in fichiers fonciers and $\mathrm{m}$ building footprints in $\mathrm{BD}-\mathrm{TOPO}$ exist on the parcel geometry. This was the more challenging case to deal with. A complex algorithm to allocate the good tabular entries to adequate building geometries is currently being investigated; this configuration is beyond the scope of this paper.

Only the three first categories of cardinality were retained; then, for the second datamerging step, when the postal addresses matched on both sides (i.e., EPD entry and the result of Step (1)), we computed top frequencies or averaged values of useful data contained in the EPD database (e.g., thermal envelop materials, type and thickness of insulation, energy equipment) by building entry. Results from the whole data-matching step are stocked in CSTB's French national building database (BDNB).

\section{(3) Sample Generation}

In the BDNB, portions of information on most of the existing buildings are present. However, some buildings are better described than others; this is because, for example, during land declarations, there was detailed feedback on most of the characteristics of the buildings or simply that the buildings have or do not have reliable $\operatorname{EPD}(\mathrm{s})$. Then, for BTP-flux, buildings with information about the use and construction year were retained, allowing general building stock segmentation. The residential building sample was selected by filtering buildings where variables about buildings' materiality were described; these variables correspond, for instance, to the walls' materials coming from the land files and the materials of the exterior walls coming from the EPDs. Non-residential buildings do not have EPDs, so buildings with complete generic information (use, construction period) were exclusively retained. This sample allowed material and equipment quantities to be calculated at the building scale for geographic units, such as district, city, region, or national scale. Results of the sample generated for the study case of the Île-de-France region are described in Section 3.1.

\subsubsection{Data Enrichment}

Before this step, each chosen building in the sample has generic information, such as use, year of construction, structural materials of the exterior walls, and specific thermal performances. However, this information is not sufficient to know the materiality of each building element (e.g., foundations, walls, floors, roofs) and to allow us subsequently to calculate the mass of materials present in the building and the waste flows that could result from it. Consequently, this step's goal is to have a detailed description of the materials and products in each element of the assessed building for each building in the sample. Then, this step was mainly based on the completion of information found on the generic information already described in the sample; for this, two consecutive substeps were carried out with two modules: the association service and TyPy.

\section{(1) Association Service}

Missing data was found using an approach based on bibliographical data and/or professional rules (e.g., following the exterior wall data information, the exterior coating or/and the nature of insulation can be completed) or based on general information present in the BDNB. Missing data could also be completed based on building segment characteristics; for instance, information, such as the thermal coefficient for a wall that allows associating the wall component to a principal material and a default or defined material thickness. 


\section{(2) TyPy: Macro-Components Catalog Development}

TyPy is a Python package developed to generate building information based on a macro-components dataset with an associated management system. The module has a multilevel tree taxonomy with an object-oriented environment, where every node has a different class and where each level of the tree corresponds to a different spatial scale (Figure 2a). In this nomenclature, the highest level corresponds to the studied unit, that is to say, a building; the lowest levels correspond to grouping levels that represent the structure of the building, such as the infrastructures, superstructures, and systems. The finest scale at the lowest level corresponds to materials and products. Nodes at the finest scale can be understood as the tree's leaves or child nodes, and a node at the next finest scale connected to the tree's leaves via the tree's branches is designated as a parent node. This data classification structure was chosen because of its functionality and because relations between classes are straightforward. The bottom-up unit assembly approach makes it possible to describe the entire building, while minimizing the information to be collected [66], because the upper classes can be calculated according to the lower classes; the upper classes can even inherit the characteristics of the lower classes.
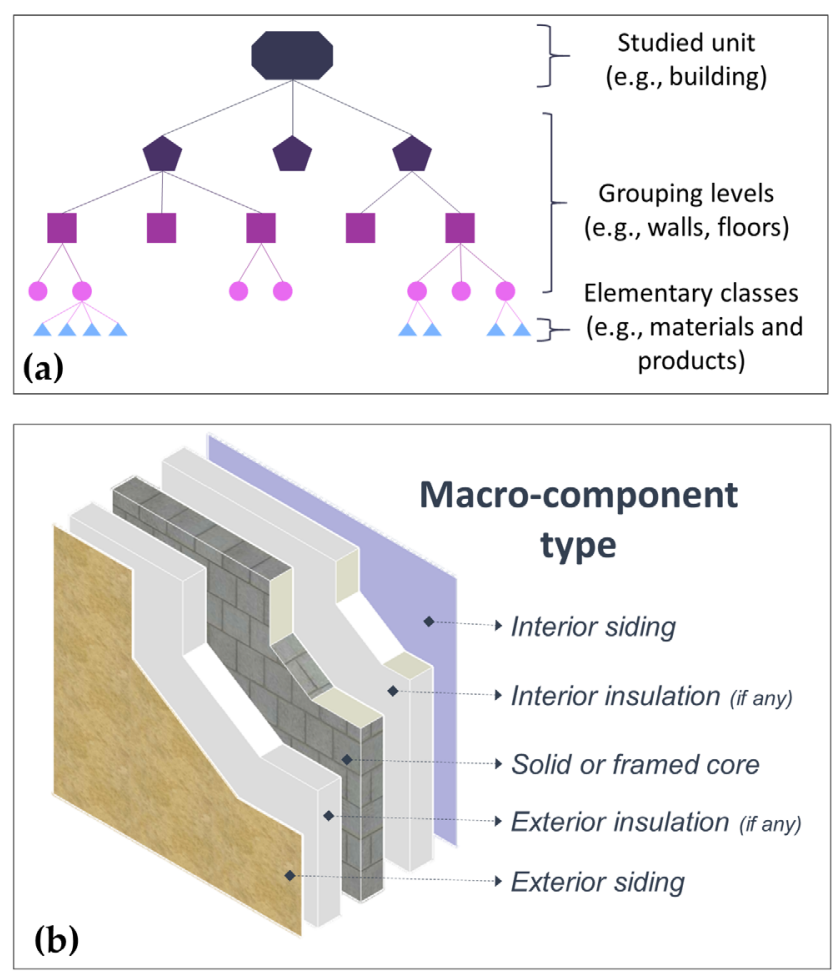

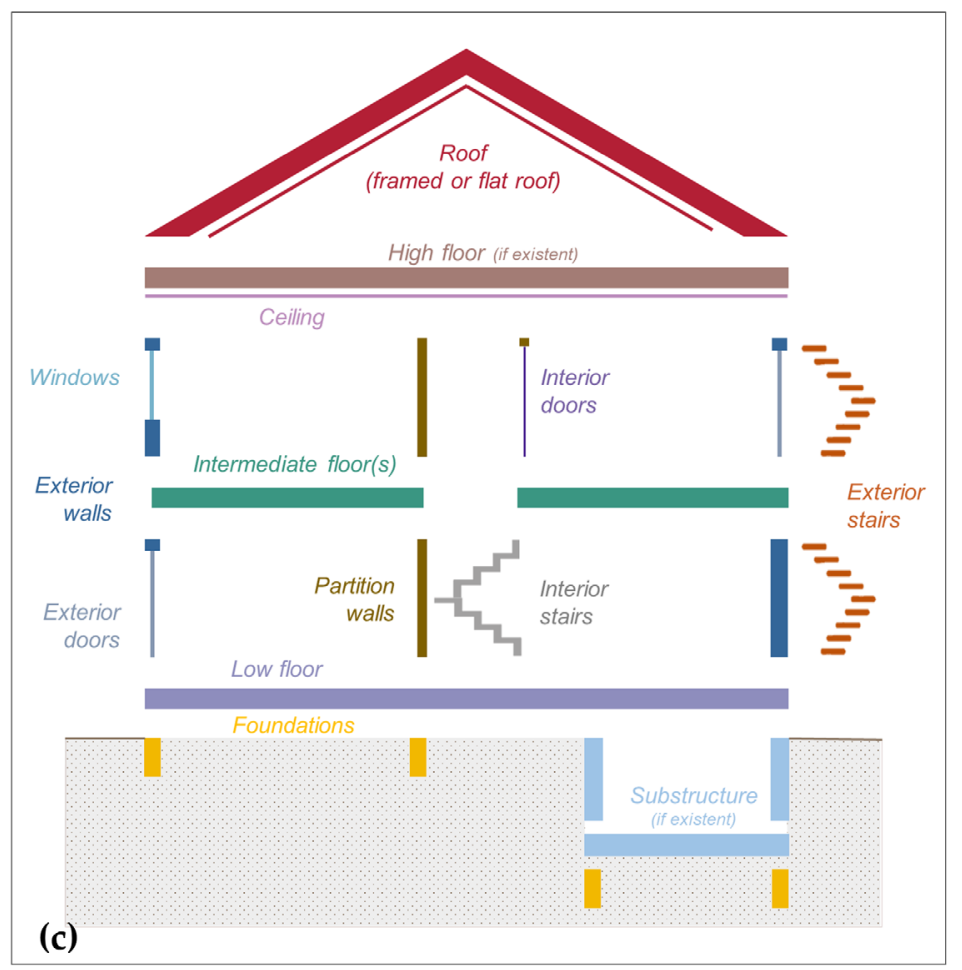

(c)

Figure 2. (a) TyPy tree nomenclature for building description, (b) macro-component type (example of an exterior wall), and (c) building decomposition by macro-components.

The information required for a detailed description of all the building's physical characteristics, both reliable and available, is difficult to retrieve at the scale of the building. Therefore, a macro-component approach was developed (Figure 2b). A macro-component is defined as the association of components and assembling; thus, the macro-components' assembling allows an ample building materials description (Figure 2c). Synthetically, describing a building is to associate, for example, an exterior wall type, a floor type, and all the interior and exterior structure macro-components types. To develop typologies of macro-components, the built stock was segmented by building use, construction period, and building elements (e.g., walls, floors). A macro-component can belong to a single period or several periods, and different building uses can share specific macro-components. Each macro-component is modeled in the database like a dimensionless object comprising its proper intrinsic properties (e.g., functional unit, density, thermal properties), plus 
the waste category composition in percentages. The macro-components catalog, with 137 macro-components types and 432 components (at July 2021), was developed using different information sources: specialized reports, scientific literature, and expert information, to structure the model. For more specifications, see Appendix A. This dataset aimed to dispose of a high number of macro-component representatives of the building stock. The modular building description by macro-components was one of the principal contributions of this methodology to describe the building stock.

\subsubsection{Modeling}

Up to this stage, the materiality of each building in the sample was extensively described. The objective at this stage is twofold: first, to give dimensions to the various macro-components of the building, for instance, length, surface, or volume (see 1) in Section 2.2.3). Then, once each macro-component was associated with the unique dimensions of each building, the masses of the materials were calculated and aggregated at the building level (see 2) in Section 2.2.3).

\section{(1) Sizing}

A geometric module was developed to complete geometric building information necessary to quantify the macro-components. IGN's BD-TOPO database provides a vector description of buildings on French territory (IGN, 2020); in the database, the height and the geographical coordinates of the footprints of the buildings are directly available. Geospatial processing makes possible the estimation of buildings' footprints, the buildings' azimuth, and the surface for every building face. The building's face surface was calculated by multiplying a segment of the building footprint by the building height. To obtain only the opaque walls, the glassed area was deducted from the total exterior wall surface. To complete this module, expert rules were implemented to size interior building structure (e.g., joist distance, loadbearing wall spacing).

\section{(2) Material Accounting}

With the detailed knowledge of the materials and products in the building, as well as their dimensions, the material quantification can take place. The building masses were calculated by waste categories (see 1) in Section 2.2.4), and according to the buildings' initial state, the renovation or reconstruction of the buildings was not taken into account. BTP-flux's tree structure allows the aggregation of material quantities at several levels; therefore, quantities of material can be obtained at the building elements level, at the building level, or at the sample level (urban, regional, national). Equation (1) illustrates a simplified mathematical representation of the mass calculation.

$$
M S_{i, k+1}=\sum_{1}^{n}\left(X_{i, k}\right)
$$

where $M S_{i, u, d}$ is the material quantity for a material category $i$, at the level $k+1$. $X_{i, k}$, calculated at the finest level by multiplying the building element size with the material mass, is the material quantity for a material category $i$ at the level $k$; and $n$ is the total number of children related to the parent assessed at the level $k$.

\subsubsection{Flow Assessment}

This step aims to systematically assess the waste flows coming from demolitions or renovations in the territorial space defined for the study case and a specific year. This quantitative procedure allows demolition waste identification and quantification; the developed model has the ambition to serve as a basis for material-flow management, because the level of detail on the potential secondary resources and wastes could minimize the waste flows and maximize the value of the resources. The waste categories considered for the BTP-flux model are specified in part 1 of Section 2.2.4. The calculation is detailed in 
part 2 of Section 2.2.4. This article focuses on demolition flows; the renovation flows will be presented in futures studies.

\section{(1) Waste Categories}

The European Directive 2008/98/E.C. establishes the legislative framework for CDW management, including achieving targets for waste collection, reuse, recycling, and recovery [67]. This directive is linked to a common terminology for classifying waste across the EU; classification refers to the types of materials (e.g., wood, plastic) and their characteristics (hazardous, non-hazardous) [68]. CDW classification is defined in chapter 17 of the European List of Waste (ELW) [69]. In France, Decree No. 2011-610, based on the aforementioned European directive, specifies the provisions relating to the diagnosis relating to the management of waste resulting from the demolition of categories of buildings [70]. The decree includes a Cerfa 14498 proofing form to facilitate the detailed, quantified, and localized inventory of materials, construction products, and equipment, as well as the possibilities of recovery [71]. This last document also lists the different categories of waste and their subcategories, 31 in total. A summary of the European classification and the French classification is given in Table 1. The BTP-flux model uses French categories and subcategories for waste classification.

Table 1. CDW classification in Europe and France.

\begin{tabular}{|c|c|c|c|c|}
\hline \multicolumn{3}{|c|}{ European Commission $[67,69]$} & \multicolumn{2}{|l|}{ France [71] } \\
\hline Code & Waste Subcategory & Waste Category & Waste Subcategory & Waste Category \\
\hline 170101 & Concrete & \multirow{5}{*}{$\begin{array}{l}\text { Concrete, bricks, tiles, } \\
\text { ceramics, and gypsum-based } \\
\text { materials } \\
(1701)\end{array}$} & Concrete and stone & IW \\
\hline 170102 & Bricks & & Tiles and bricks & IW \\
\hline 170103 & Tiles and ceramics & & $\begin{array}{l}\text { Ceramic (tiling, earthenware, } \\
\text { and sanitary ware) }\end{array}$ & IW \\
\hline 170104 & $\begin{array}{l}\text { Gypsum-based construction } \\
\text { materials }\end{array}$ & & Gypsum & NHW \\
\hline 170105 & $\begin{array}{l}\text { Asbestos-based construction } \\
\text { materials }\end{array}$ & & Asbestos & HW \\
\hline 170201 & Wood & \multirow{4}{*}{$\begin{array}{l}\text { Wood, glass and plastic } \\
(1702)\end{array}$} & Glass without joinery & IW \\
\hline 170202 & Glass & & Wood & NHW \\
\hline \multirow[t]{2}{*}{170203} & \multirow[t]{2}{*}{ Plastics } & & $\begin{array}{l}\text { Treated wood containing } \\
\text { dangerous substances }\end{array}$ & HW \\
\hline & & & Plastics & NHW \\
\hline 170301 & Asphalt containing tar & \multirow{4}{*}{$\begin{array}{l}\text { Asphalt, tar and tarred } \\
\text { products } \\
(1703)\end{array}$} & $\begin{array}{l}\text { Bituminous mixtures without } \\
\text { tar }\end{array}$ & IW \\
\hline 170302 & Asphalt not containing tar & & $\begin{array}{l}\text { Waterproofing complex } \\
\text { without tar }\end{array}$ & NHW \\
\hline \multirow{2}{*}{170303} & \multirow{2}{*}{ Tar and tar products } & & $\begin{array}{l}\text { Waterproofing complex } \\
\text { containing tar }\end{array}$ & HW \\
\hline & & & $\begin{array}{l}\text { Bituminous mixtures } \\
\text { containing tar }\end{array}$ & HW \\
\hline 170401 & Copper, bronze, brass & \multirow{8}{*}{$\begin{array}{l}\text { Metals (including their alloys) } \\
(1704)\end{array}$} & \multirow{8}{*}{ Metals } & \multirow{8}{*}{ NHW } \\
\hline 170402 & Aluminum & & & \\
\hline 170403 & Lead & & & \\
\hline 170404 & Zinc & & & \\
\hline 170405 & Iron and steel & & & \\
\hline 170406 & Tin & & & \\
\hline 170407 & Mixed metals & & & \\
\hline 170408 & Cables & & & \\
\hline
\end{tabular}


Table 1. Cont.

\begin{tabular}{|c|c|c|c|c|}
\hline \multicolumn{3}{|c|}{ European Commission $[67,69]$} & \multicolumn{2}{|l|}{ France [71] } \\
\hline Code & Waste Subcategory & Waste Category & Waste Subcategory & Waste Category \\
\hline 170503 & $\begin{array}{l}\text { Soil and stones containing } \\
\text { dangerous substances }\end{array}$ & \multirow{4}{*}{$\begin{array}{l}\text { Soil (including excavated soil } \\
\text { from contaminated sites), } \\
\text { stones, and dredging spoil } \\
\text { (17 05) }\end{array}$} & $\begin{array}{l}\text { Soils (excluding topsoil) } \\
\text { unpolluted }\end{array}$ & IW \\
\hline 170504 & $\begin{array}{l}\text { Soil and stones other than } \\
\text { those mentioned in } 170503\end{array}$ & & Plants & NHW \\
\hline 170505 & $\begin{array}{l}\text { Dredging spoil containing } \\
\text { dangerous substances }\end{array}$ & & Topsoil & NHW \\
\hline 170506 & $\begin{array}{l}\text { Dredging spoil other than } \\
\text { those mentioned in } 170505\end{array}$ & & $\begin{array}{l}\text { Soils containing hazardous } \\
\text { substances }\end{array}$ & $\mathrm{HW}$ \\
\hline 170601 & $\begin{array}{l}\text { Insulation materials containing } \\
\text { asbestos }\end{array}$ & \multirow{2}{*}{$\begin{array}{l}\text { Insulation materials } \\
(1706)\end{array}$} & Insulation materials & NHW \\
\hline 170602 & Other insulation materials & & $\begin{array}{l}\text { Insulation materials containing } \\
\text { asbestos }\end{array}$ & HW \\
\hline 170702 & $\begin{array}{l}\text { Mixed construction and } \\
\text { demolition waste or separated } \\
\text { fractions containing dangerous } \\
\text { substances }\end{array}$ & \multirow{2}{*}{$\begin{array}{l}\text { Mixed construction and } \\
\text { demolition waste } \\
(1707)\end{array}$} & $\begin{array}{l}\text { Mixtures of inert waste } \\
\text { without non-hazardous waste }\end{array}$ & IW \\
\hline \multirow[t]{11}{*}{170703} & $\begin{array}{l}\text { Mixed construction and } \\
\text { demolition waste other than } \\
\text { those mentioned in } 170702\end{array}$ & & $\begin{array}{l}\text { Mixtures of non-hazardous } \\
\text { waste }\end{array}$ & NHW \\
\hline & & & $\begin{array}{l}\text { Windows and others glazed } \\
\text { openings }\end{array}$ & NHW \\
\hline & & & Floor coverings & NHW \\
\hline & & & $\begin{array}{l}\text { Wastes from electrical and } \\
\text { electronic equipment }\end{array}$ & NHW \\
\hline & & & $\begin{array}{l}\text { Paints containing dangerous } \\
\text { substances }\end{array}$ & $\mathrm{HW}$ \\
\hline & & & $\begin{array}{l}\text { Heating, air conditioning, or } \\
\text { refrigeration equipment } \\
\text { containing hazardous } \\
\text { refrigerants }\end{array}$ & HW \\
\hline & & & $\begin{array}{l}\text { Light sources (fluorescent } \\
\text { tubes, neon lights, discharge } \\
\text { lamps, LED lamps) }\end{array}$ & $\mathrm{HW}$ \\
\hline & & & $\begin{array}{l}\text { Other wastes from electrical } \\
\text { and electronic equipment } \\
\text { containing dangerous } \\
\text { substances }\end{array}$ & $\mathrm{HW}$ \\
\hline & & & Other inert waste & IW \\
\hline & & & Other non-hazardous waste & NHW \\
\hline & & & Other hazardous waste & HW \\
\hline
\end{tabular}

\section{(2) Material-Flow Estimation}

The BTP-flux model aims to estimate, in a differentiated manner, the demolition flux by waste category. The calculation of flows for residential buildings focused on buildings constructed from 1945 to 1970. In France, buildings produced between this period present pathologies due to their design and construction, mainly thermal problems (e.g., significant thermal bridges). In addition, the architectural quality of these buildings is not famous compared to older buildings in the territory, for instance, the so-called Haussmann buildings; therefore, buildings built between this period will be probably deconstructed. Demolition rates were not applied to previous periods, as it was assumed that pre-1945 buildings will be preserved for their architectural quality and renovated rather than demolished. For non-residential buildings, the demolition rates were applied 
to all periods, because their lifespan is mainly linked to investment strategies and the obsolescence of the buildings.

In a general way, total waste quantities were calculated as the aggregation of the waste of each subelement (such as a wall, floor, roof) of the building structure, consisting of a collection of macro-elements. Equation (2) gives the detailed mathematical representation of demolition-flow calculation for a territory. Flows were estimated by multiplying the material account for the period under assessment with a high and low deconstruction rate determined for each type of use; these values are given in Table 2 . The demolition rates were calculated for the residential sector based on the number of dwellings demolished yearly and the total number of dwellings in the territory reported to the number of dwellings for the construction period under assessment [72-76]. For the non-residential sector, demolition rates were calculated based on the areas deconstructed per year and the total area of a building-use segment in the territory. A low and high threshold for the number of demolished dwellings or demolished surfaces was taken according to a literature review [72-76]. This threshold is defined as between 35,000 and 95,000 dwellings demolished per year for the residential sector, between 1.8 and 8 million $\mathrm{m}^{2}$ for non-residential uses as offices or education buildings, and 5.5 million $\mathrm{m}^{2}$ demolished per year in the case of industrial buildings. The aforementioned figures correspond to the total over the French territory; subsequently, all the demolition rates were calculated as a function of the surface or dwelling's weight for a building-use segment in the territory.

$$
M F_{i, u, d}^{t}=\sum M S_{i, u, d}^{t} \times R_{u}
$$

where $M F_{i, n, m, k}^{t}$ is a waste category $i$ calculated for year $t$, building use $u$, and construction period $d$ and $R_{u}$ is the demolition rate for building use $d$.

Table 2. Demolition rates for waste-flow calculation.

\begin{tabular}{lcc}
\hline Building Use & Low Value & High Value \\
\hline Individual housing & 0.00825 & 0.02258 \\
\hline Collective housing & 0.00474 & 0.01297 \\
\hline Industrial & 0.00730 & 0.00730 \\
\hline Office and education & 0.00212 & 0.00940 \\
\hline
\end{tabular}

\subsubsection{Extrapolation}

The association of all the past steps allowed us to obtain the nature and quantity of material stocks and flows in the building stock at the sample level. To obtain the materiality at the territory level, extrapolation was necessary (Figure 3). By statistical inference (extrapolation), the building stock characteristics can be estimated for the total population since the sample was representative of the population. However, since the sample was only a part of the whole, extrapolation can inevitably lead to errors of two types: random errors due to sampling and systematic errors not due to sampling. Concerning the systematic error, it is not treated in this article. Nevertheless, concerning the random error, the larger the sample, the smaller the random error, which is why all the reliable units resulting from the cross-referencing of the data were processed (101,320 buildings) instead of a representative subsample (estimated at around 1540 units). Random errors result from the probability of obtaining the correct rate of units for the population during the sampling step. Sample stratification could improve precision and accuracy for the extrapolation when relevant variables are available for the population. Since the evaluated sample was constructed according to the available data, the rate of segments or "strata" (building use, construction period, and wall material) was not precisely that of the segments in the population. Failure to use appropriate rates usually results in bias, which can be significant in certain circumstances. The unbiased Horvitz-Thompson estimator [77], for example, 
weights each unit according to the inverse of its probability of selection; it is mathematically expressed in Equation (3):

$$
\hat{\tau}_{\pi}=\sum_{i=1}^{v} \pi_{i}^{-1} \times Y_{i}
$$

where $v$ represents the number of distinct units on the strata, $\pi_{i}$ is the inclusion probability of unit $i$ sampled from the total population and belonging to the same strata $(Y)$.

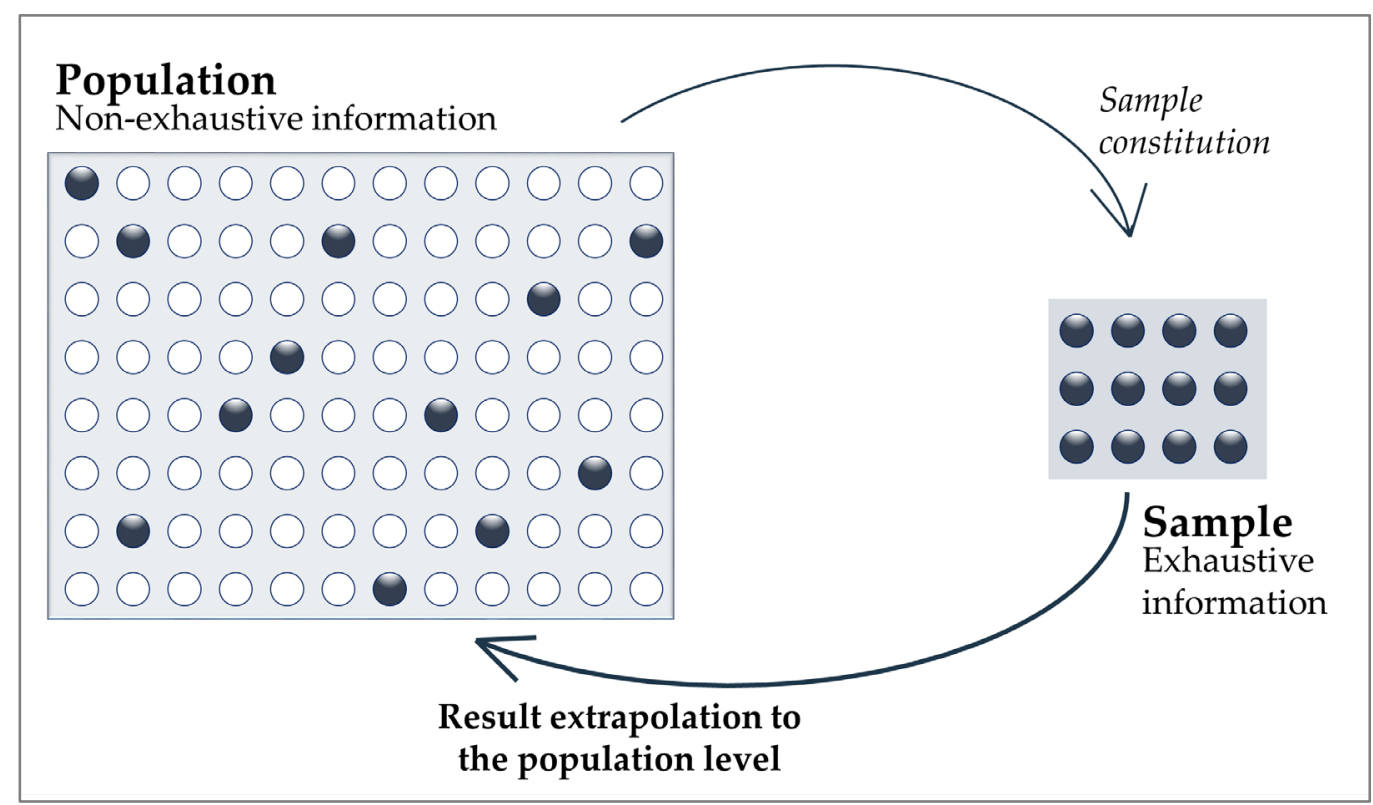

Figure 3. Schematic representation of extrapolation step.

The main objective of this step for this study is to conserve the statistic weight for every category of the building segmentation and extend the sample result to all the population to obtain the absolute quantities representing the materiality of the building stock and demolition flows for all the territory. The methodology for extrapolating was structured in four main steps. First, the population was segmented by building use, construction period, and structural material (information available in the land files database), and a statistical weight was calculated for every segment using the joint law probability [78] and based on the Horvitz-Thompson estimator. Strata rates were calculated for the sample (matrix S) and the population (matrix $P$ ). Then, the estimator factor was calculated between the sample and the population to obtain the same rate of surface for every segment (matrix $F$ ). The strata sample rates multiplied by the estimator factor allowed us to obtain the correct rates at the population level. This step's purpose is to have a good representation of the material and construction system. Equations (4) and (5) show a generic mathematical representation of extrapolation at the building segmentation level. Then, a statistical weight was reported at the building level in the sample $\left(f_{d, m, u}\right)$. Finally, results were extrapolated from the sample to the population, multiplying the building level results by the building's statistical weight.

$$
S_{u, d, m} \times F_{u, d, m}=P_{u, d, m}
$$

$\left(\begin{array}{cccc}s_{1,1} & s_{1,2} & \ldots & s_{1, m} \\ s_{2,1} & s_{2,2} & \ldots & s_{2, m} \\ \ldots & \ldots & \ldots & \ldots \\ s_{d, 1} & s_{d, 2} & \ldots & s_{d, m}\end{array}\right)_{u}+\left(\begin{array}{cccc}f_{1,1} & f_{1,2} & \ldots & f_{1, m} \\ f_{2,1} & f_{2,2} & \ldots & f_{2, m} \\ \ldots & \ldots & \ldots & \ldots \\ f_{d, 1} & f_{d, 2} & \ldots & f_{d, m}\end{array}\right)_{u}=\left(\begin{array}{cccc}p_{1,1} & p_{1,2} & \ldots & p_{1, m} \\ p_{2,1} & p_{2,2} & \ldots & p_{2, m} \\ \ldots & \ldots & \ldots & \ldots \\ p_{d, 1} & p_{d, 2} & \ldots & p_{d, m}\end{array}\right)_{u}$

where $S_{u, m, p}$ is the matrix with the ratios of a building's floor area rate for each segment in the sample as a function of building use $u$, the construction period $d$, and the type of wall 
material $m . F_{u, m, p}$ is the matrix with the estimated factors, and, $P_{u, m, p}$ is the matrix with the building's floor area rate for each segment in the population.

\subsection{Case Study}

This section describes the Île-de-France case study and the selected system boundary. The boundaries selection was essential because it determined the extent of flows within a territory [79]. The urban metabolism analysis scale can bring out different indicators linked to the complexity of the socioeconomic and environmental metabolic dynamics; therefore, considering a multigeographic scale is essential for developing backcasting and forecasting scenarios that can be applied to formulate CE strategies. The Île-de-France region-Figure 4-has eight administrative divisions called departments with an estimated 12 million inhabitants in 2021 over an area of $12,012 \mathrm{~km}^{2}$ [80]. The intraregional areas (Paris (P), Petit Couronne (PC), and Grande Couronne (GC)), a group of several departments, have very different morphological tissues; for instance, Paris and the PC have a high level of urbanization in comparison with the GC. At the same time, the density within the urbanized area in Paris is about three times that of the PC and about eight times that of the GC. This population has grown at the rate of around 50,000 inhabitants per year for 30 years [81]. Besides, the region is a large consumer of resources, mostly imported resources [58]. In a national context of the fight against climate change and the face of environmental, economic, and societal challenges, the region is one of the pioneer regions seeking its resilience by implementing the $C E$ in its initiatives, such as the $C$ and D waste management plan (PRPGD) [82], or other documents of urban planning elaborated at the regional scale and also deployed at lower administrative scales [83]. One of the main lines of action is the building sector, where the main objectives are to bring out and support innovative initiatives during construction, renovation, or deconstruction operations to integrate the CE's principles into the sector to make it sober in the use of resources, sustainable, and resilient. Thus, the analysis and knowledge of building stock and flows are necessary to give better visibility to the resources that make up the urban mine and allow decisionmakers to develop suitable strategies for the sector. Hence, the Île-de-France region is a pertinent territory to analyze building material stock and flows. 


\begin{tabular}{|c|c|c|c|}
\hline Île-de-France region & & & \\
\hline \multicolumn{4}{|l|}{$\begin{array}{l}\text { Population: } \\
12.3 \text { million }\end{array}$} \\
\hline \multicolumn{4}{|l|}{$\begin{array}{l}\text { Surface area: } \\
\qquad 12,065 \mathrm{~km}^{2}\end{array}$} \\
\hline \multicolumn{4}{|l|}{$\begin{array}{l}\text { Gross density: } \\
1021 \text { inhab } / \mathrm{km}^{2}\end{array}$} \\
\hline \multicolumn{4}{|l|}{$\begin{array}{l}\text { Density within the } \\
\text { urbanized area: } \\
\qquad 4561 \text { inhab/ } \mathrm{km}^{2}\end{array}$} \\
\hline \multirow{4}{*}{\multicolumn{4}{|c|}{$\begin{array}{l}75 \text { - Paris } \\
77 \text { - Seine-et-Marne } \\
78 \text { - Yvelines } \\
91 \text { - Essonne } \\
92 \text { - Hauts-de-Seine } \\
93 \text { - Seine-Saint-Denis } \\
94 \text { - Val-de-Marne } \\
95 \text { - Val-d'Oise }\end{array}$}} \\
\hline & & & \\
\hline & & & \\
\hline & & & \\
\hline & Paris $(\mathbf{P})$ & Petite Couronne (PC) & Grande Couronne (GC) \\
\hline$\perp$ Notionolanitol & $\begin{array}{l}105.4 \mathrm{~km}^{2} \\
2.1 \mathrm{million} \\
20,320 \text { inhab } / \mathrm{km}^{2} \text { - gross density }\end{array}$ & $\begin{array}{l}657.2 \mathrm{~km}^{2} \\
4.7 \text { million } \\
7183 \text { inhab } / \mathrm{km}^{2} \text { - gross density }\end{array}$ & $\begin{array}{l}11,302 \mathrm{~km}^{2} \\
5.4 \text { million } \\
483 \text { inhab } / \mathrm{km}^{2} \text { - gross density }\end{array}$ \\
\hline $\begin{array}{c}\star \quad \text { National capital } \\
\text { Source: data from INSEE - RP } 2021 \text {, } \\
\text { MOS 2017, background from IGN }\end{array}$ & $\begin{array}{l}89 \% \text { urbanized } \\
22,831 \text { inhab } / \mathrm{km}^{2} \text { - density within } \\
\text { the urbanized area }\end{array}$ & $\begin{array}{l}84 \% \text { urbanized } \\
8551 \text { inhab } / \mathrm{km}^{2} \text { - density within } \\
\text { the urbanized area }\end{array}$ & $\begin{array}{l}18 \% \text { urbanized } \\
2684 \text { inhab/km² - density within } \\
\text { the urbanized area }\end{array}$ \\
\hline
\end{tabular}

Figure 4. Île-de-France region: population, surface, urbanized area ratio, and population density.

\section{Results}

This section reports the results of the study of the Ille-de-France region. The first result came from geospatial processing and allowed analysis of the geometry of buildings. Then, stock in building structures is presented with their spatial distribution and material composition by macro-components and secondary resources category. Finally, the secondary resource material flows generated by building demolition are described for every segment of building stock studied.

\subsection{Ile-de-France Sample Description}

For the Île-de-France regional study case, the retained sample comprised 88,688 residential buildings (Figure 5a) and 12,632 non-residential buildings (Figure 5b). For segmentation, classified in the residential sector were individual houses (IH) and multifamily houses (MF); for the non-residential sector, only office, industrial, and education buildings were considered in this study due to data availability; the three non-residential mentioned sectors were those who have the most presence in the sector. 

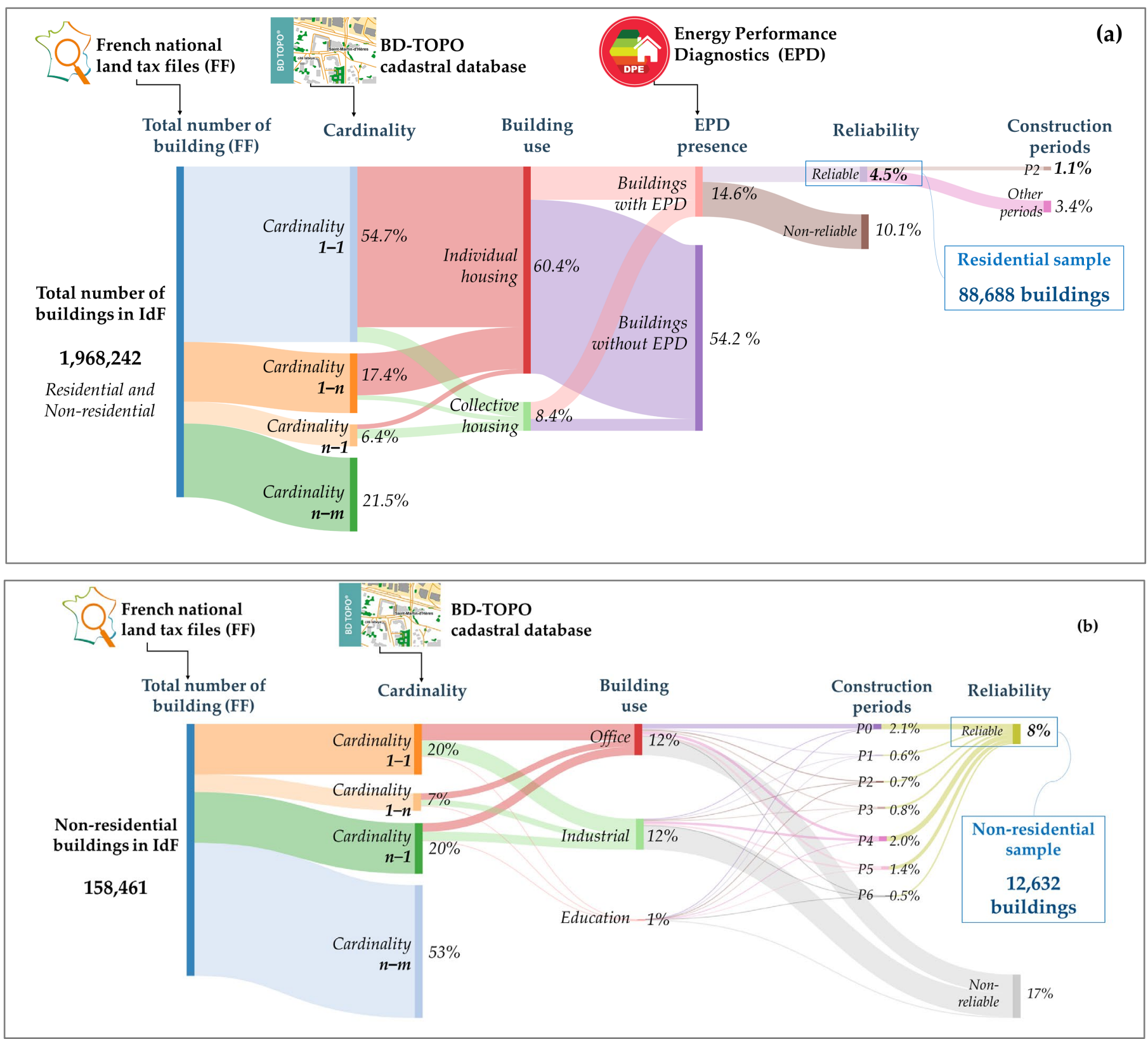

Figure 5. Results of cross referencing the databases and size of the residential sample (a) and the non-residential sample (b) studied for IdF region. The ratio between the total number of buildings, the cardinality, the building use, the presence of an EPD in the residential building, the construction period, and the reliability of data.

The building stock was also segmented into seven construction periods: P0 (before 1919), P1 (1919-1944), P2 (1945-1970), P3 (1971-1989), P4 (1990-2004), P5 (2005-2012), P6 (2013-2019). For flow analysis, in the case of residential houses, only period P2 was analyzed, and in the case of non-residential houses, all periods were considered.

An analyzed sample for the Île-de-France region represented $4.5 \%$ of the total buildings in the region, and non-residential analyzed buildings represented $8 \%$ of the total nonresidential buildings. Table 3 gives the ratios of built surfaces studied. The buildings analyzed at the scale of the territory represented $87 \%$ of the total built stock. Percentages for the sample were calculated based on the total for the building use segment. 
Table 3. Ratio of constructed surfaces at the sample and population levels.

\begin{tabular}{ccc}
\hline Building Use & Population & Sample \\
\hline Individual housing & $28.55 \%$ & $6.10 \%$ \\
\hline Collective housing & $40.73 \%$ & $1.20 \%$ \\
\hline Industrial & $6.81 \%$ & $11.00 \%$ \\
\hline Office & $10.21 \%$ & $16.10 \%$ \\
\hline Education & $0.64 \%$ & $7.80 \%$ \\
\hline Other & $12.85 \%$ & \\
\hline Unknown & $0.21 \%$ & \\
\hline Total & $\mathbf{1 0 0 . 0 0 \%}$ & $\mathbf{4 . 5 0 \%}$ \\
\hline
\end{tabular}

\subsection{Geometrical Characteristics of the Studied Buildings for the Ille-de-France Region}

Systematic geospatial processing and data analysis allowed the estimation of some of the principal features for the sample of 101,320 studied buildings and the total population. The geometrical results of Table 4 by building use and construction period give an overview of the region's building distribution. IH represented almost $25 \%$ of the total floor area; nevertheless, it accounted for $45 \%$ of the constructed ground area; in contrast, $\mathrm{CH}$ accounted for $47 \%$ of the total floor area, covering only $29 \%$ of the ground area. Concerning the nonresidential sectors, the ratio between the occupied areas on the ground and the total floor areas was equivalent.

The ancient building stock in Île-de-France, built before 1945, represented $28 \%$ of the total stock studied, of which residential buildings accounted for $26.2 \%$ of this ancient building stock. The economic boom and demographics of the region between 1945 and 1990 increased the number of constructions; $41 \%$ of the existing stock was built during this period. The number of buildings since 1990 was more modest; it represented $31 \%$ of the remaining stock. Paris is the territory with the most ancient buildings; they represented $47 \%$ of the building stock, while the PC accounted for more than $23 \%$ and the GC for $21 \%$. After the 1990s, the construction of residential buildings took place mainly in GC and PC, which regrouped $26 \%$ of residential buildings against $14 \%$ for Paris.

Caution should be made regarding the construction period, as this information relates to the original construction date and does not consider changes due to renovations or reconstructions. Although for periods that were under-represented in the sample, the extrapolation step made possible the correction of the ratios of built surfaces. Results also showed that $44 \%$ of the stock was built before 1970 and that the building stock built between 1970 and 1990 accounted for more than $18 \%$ of the total floor surface studied constructed in the region.

Individual housings were principally presented in PC and GC subregions while collective housings were distributed all along with the subregions. The average height for buildings changed according to the construction period. In the case of $\mathrm{CH}$, the average went from $10.7 \mathrm{~m}$ to $6.2 \mathrm{~m}$; in the case of $\mathrm{IH}$, the average height remained around $5 \mathrm{~m}$. For non-residential buildings, the average height was similar in the different construction periods. Figure A1 in Appendix B gives an overview of the height of buildings, by height groups, in the region. 
Table 4. Ground and floor areas for buildings segments (sample and population) in Île-de-France.

\begin{tabular}{|c|c|c|c|c|c|c|c|c|c|}
\hline \multirow{3}{*}{ Building Use } & \multirow{3}{*}{$\begin{array}{l}\text { Construction } \\
\text { Period }\end{array}$} & \multicolumn{4}{|c|}{ Sample } & \multicolumn{4}{|c|}{ Population } \\
\hline & & \multicolumn{2}{|c|}{ Ground Area } & \multicolumn{2}{|c|}{ Floor Area } & \multicolumn{2}{|c|}{ Ground Area } & \multicolumn{2}{|c|}{ Floor Area } \\
\hline & & $\begin{array}{l}\text { Million } \\
\mathrm{m}^{2}\end{array}$ & Proportion & $\begin{array}{l}\text { Million } \\
\mathrm{m}^{2}\end{array}$ & Proportion & $\begin{array}{l}\text { Million } \\
\mathrm{m}^{2}\end{array}$ & Proportion & $\begin{array}{c}\text { Million } \\
\mathrm{m}^{2}\end{array}$ & Proportion \\
\hline \multirow{7}{*}{$\begin{array}{l}\text { Collective } \\
\text { housing (CH) }\end{array}$} & P0 (before 1919) & 0.57 & $1.20 \%$ & 2.33 & $3.80 \%$ & 29.41 & $2.10 \%$ & 114.91 & $5.70 \%$ \\
\hline & P1 (1919-1944) & 0.17 & $0.40 \%$ & 0.64 & $1.60 \%$ & 12.77 & $0.60 \%$ & 48.77 & $2.40 \%$ \\
\hline & P2 (1945-1970) & 0.49 & $1.00 \%$ & 2.20 & $6.30 \%$ & 48.96 & $2.00 \%$ & 219.56 & $10.90 \%$ \\
\hline & P3 (1971-1989) & 0.54 & $1.10 \%$ & 2.42 & $6.10 \%$ & 47.66 & $2.20 \%$ & 209.08 & $10.40 \%$ \\
\hline & P4 (1990-2004) & 1.27 & $2.60 \%$ & 4.86 & $6.00 \%$ & 46.80 & $4.40 \%$ & 189.59 & $9.40 \%$ \\
\hline & P5 (2005-2012) & 0.84 & $1.70 \%$ & 3.12 & $3.10 \%$ & 24.33 & $2.90 \%$ & 91.00 & $4.50 \%$ \\
\hline & P6 (2013-2019) & 0.22 & $0.50 \%$ & 0.80 & $2.30 \%$ & 17.87 & $0.70 \%$ & 63.57 & $3.20 \%$ \\
\hline \multirow{7}{*}{$\begin{array}{l}\text { Individual } \\
\text { housing (IH) }\end{array}$} & P0 (before 1919) & 0.56 & $1.20 \%$ & 0.85 & $8.40 \%$ & 65.98 & $0.80 \%$ & 100.18 & $5.00 \%$ \\
\hline & P1 (1919-1944) & 0.80 & $1.70 \%$ & 1.11 & $6.10 \%$ & 48.00 & $1.00 \%$ & 69.81 & $3.50 \%$ \\
\hline & P2 (1945-1970) & 4.82 & $10.00 \%$ & 6.92 & $7.60 \%$ & 59.65 & $6.30 \%$ & 85.53 & $4.30 \%$ \\
\hline & P3 (1971-1989) & 9.19 & $19.10 \%$ & 11.81 & $13.60 \%$ & 106.68 & $10.80 \%$ & 137.30 & $6.80 \%$ \\
\hline & P4 (1990-2004) & 3.99 & $8.30 \%$ & 5.52 & $5.90 \%$ & 46.50 & $5.10 \%$ & 65.52 & $3.30 \%$ \\
\hline & P5 (2005-2012) & 1.56 & $3.20 \%$ & 2.35 & $2.50 \%$ & 19.85 & $2.20 \%$ & 30.67 & $1.50 \%$ \\
\hline & P6 (2013-2019) & 0.25 & $0.50 \%$ & 0.41 & $1.10 \%$ & 8.42 & $0.40 \%$ & 13.49 & $0.70 \%$ \\
\hline \multirow{7}{*}{ Office } & P0 (before 1919) & 2.76 & $5.70 \%$ & 11.90 & $4.20 \%$ & 32.78 & $10.90 \%$ & 131.77 & $6.60 \%$ \\
\hline & P1 (1919-1944) & 0.50 & $1.00 \%$ & 1.89 & $1.00 \%$ & 7.51 & $1.70 \%$ & 24.50 & $1.20 \%$ \\
\hline & P2 (1945-1970) & 0.61 & $1.30 \%$ & 1.78 & $1.70 \%$ & 13.54 & $1.60 \%$ & 39.68 & $2.00 \%$ \\
\hline & P3 (1971-1989) & 1.02 & $2.10 \%$ & 3.16 & $1.60 \%$ & 12.32 & $2.90 \%$ & 35.57 & $1.80 \%$ \\
\hline & P4 (1990-2004) & 2.66 & $5.50 \%$ & 8.02 & $2.60 \%$ & 20.60 & $7.30 \%$ & 63.06 & $3.10 \%$ \\
\hline & P5 (2005-2012) & 2.36 & $4.90 \%$ & 8.49 & $1.60 \%$ & 12.48 & $7.80 \%$ & 44.75 & $2.20 \%$ \\
\hline & P6 (2013-2019) & 0.71 & $1.50 \%$ & 2.31 & $0.80 \%$ & 6.45 & $2.10 \%$ & 20.57 & $1.00 \%$ \\
\hline \multirow{7}{*}{ Industrial } & P0 (before 1919) & 0.49 & $1.00 \%$ & 1.15 & $0.90 \%$ & 7.38 & $1.00 \%$ & 16.95 & $0.80 \%$ \\
\hline & P1 (1919-1944) & 0.19 & $0.40 \%$ & 0.34 & $0.50 \%$ & 3.95 & $0.30 \%$ & 7.56 & $0.40 \%$ \\
\hline & P2 (1945-1970) & 0.53 & $1.10 \%$ & 0.97 & $1.10 \%$ & 8.80 & $0.90 \%$ & 15.59 & $0.80 \%$ \\
\hline & P3 (1971-1989) & 1.73 & $3.60 \%$ & 3.57 & $1.70 \%$ & 13.57 & $3.30 \%$ & 30.04 & $1.50 \%$ \\
\hline & P4 (1990-2004) & 4.22 & $8.80 \%$ & 8.62 & $3.00 \%$ & 23.50 & $7.90 \%$ & 50.25 & $2.50 \%$ \\
\hline & P5 (2005-2012) & 3.48 & $7.20 \%$ & 7.76 & $2.40 \%$ & 18.77 & $7.10 \%$ & 42.24 & $2.10 \%$ \\
\hline & P6 (2013-2019) & 1.17 & $2.40 \%$ & 2.80 & $1.40 \%$ & 11.08 & $2.60 \%$ & 33.46 & $1.70 \%$ \\
\hline \multirow{7}{*}{ Education } & P0 (before 1919) & 0.08 & $0.20 \%$ & 0.26 & $0.20 \%$ & 1.27 & $0.20 \%$ & 3.58 & $0.20 \%$ \\
\hline & P1 (1919-1944) & 0.02 & $0.00 \%$ & 0.04 & $0.00 \%$ & 0.06 & $0.00 \%$ & 0.17 & $0.00 \%$ \\
\hline & P2 (1945-1970) & 0.02 & $0.00 \%$ & 0.05 & $0.10 \%$ & 0.44 & $0.00 \%$ & 1.05 & $0.10 \%$ \\
\hline & P3 (1971-1989) & 0.03 & $0.10 \%$ & 0.06 & $0.10 \%$ & 0.69 & $0.10 \%$ & 1.77 & $0.10 \%$ \\
\hline & P4 (1990-2004) & 0.14 & $0.30 \%$ & 0.35 & $0.20 \%$ & 1.76 & $0.30 \%$ & 3.49 & $0.20 \%$ \\
\hline & P5 (2005-2012) & 0.11 & $0.20 \%$ & 0.33 & $0.10 \%$ & 1.09 & $0.30 \%$ & 2.86 & $0.10 \%$ \\
\hline & P6 (2013-2019) & 0.05 & $0.10 \%$ & 0.14 & $0.10 \%$ & 0.96 & $0.10 \%$ & 2.58 & $0.10 \%$ \\
\hline Total & & 48.12 & $100.00 \%$ & 109.28 & $100.00 \%$ & 781.89 & $100.00 \%$ & 2010.48 & $100 \%$ \\
\hline
\end{tabular}

\subsection{Material Mass Calculation Results}

Material mass was first aggregated at the building level and only in the assessed sample. Two main observations of the mass of building as a function of the principal structural period or its construction period were observed: (1) Figure 6a shows the material stock weight per floor square meter as a function of the structural wall material. In the EPD database, information on the materiality of the building envelope is provided; one of 
the variables is the materials of the walls. The stock weight was calculated at the building level; the median of the stock weights was estimated according to each material input for residential buildings. The values showed that IH (Individual housing) stored more materials per square meter than $\mathrm{CH}$; the average variation was $20 \%$ more stock per square meter. Generically, the heaviest buildings were stone structures, followed by poured concrete, then buildings constructed with masonry elements. (2) Figure $6 \mathrm{~b}$ illustrates the evolution of the stock quantities by $\mathrm{m}^{2}$ according to the building use and the construction period. Construction periods between 1919 and 1970 contained the buildings whose weight per $\mathrm{m}^{2}$ was the highest; this varied between 700 tons per $\mathrm{m}^{2}$ and 925 tons per $\mathrm{m}^{2}$. Stock per $\mathrm{m}^{2}$ was more significant for residential uses than non-residential uses. For residential uses, stock varied between 760 tons per $\mathrm{m}^{2}$ and 950 tons per $\mathrm{m}^{2}$; the IH was slightly heavier before 1990 than after this year. If we are interested in the stock of materials in relation to the ground area, a single-family house stores, on average, $1 \mathrm{kt} / \mathrm{m}^{2}$; while a building for collective use stores an average of $2.25 \mathrm{kt} / \mathrm{m}^{2}$. Regarding non-residential buildings, offices store an average of $1.15 \mathrm{kt} / \mathrm{m}^{2}$; and education and industrial buildings are around $1 \mathrm{kt} / \mathrm{m}^{2}$.

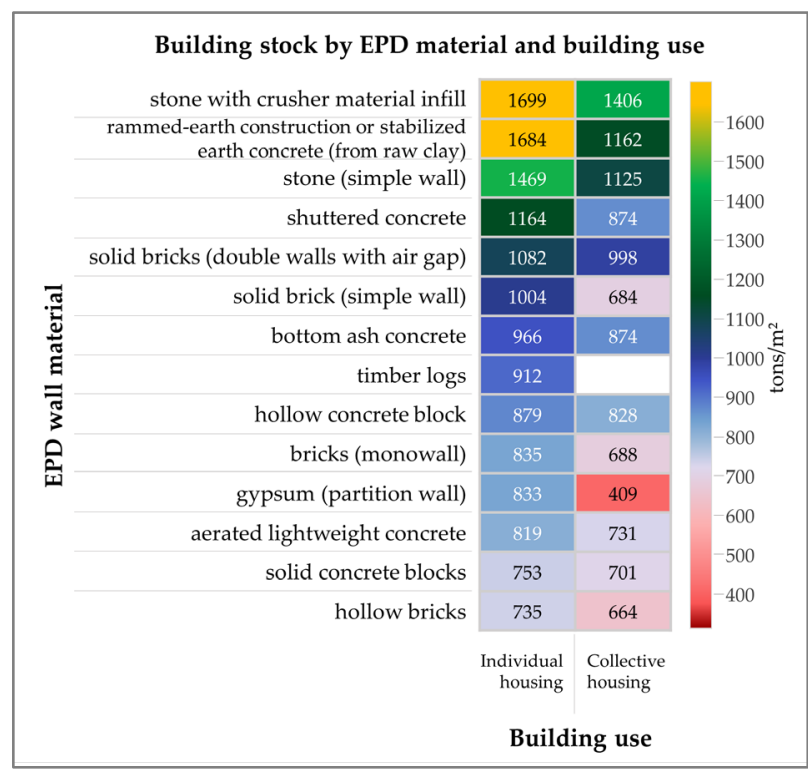

(a)

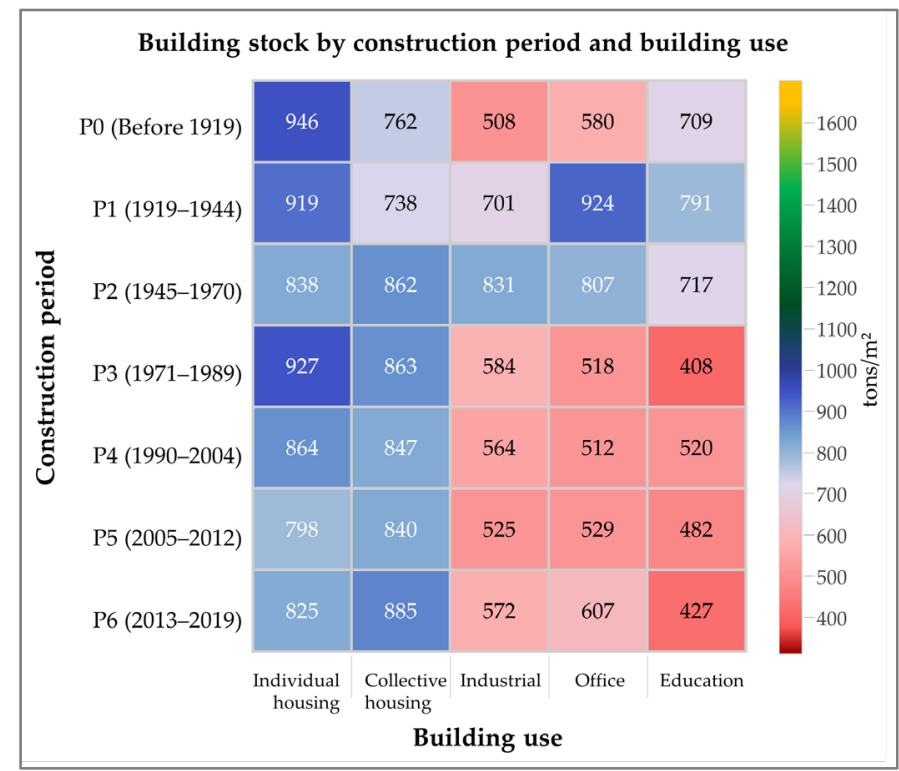

(b)

Figure 6. (a) Stock weight per square meter of constructed area of buildings based on the building use and the wall structure declared in EPDs. (b) Evolution of the stock weight per square meter of constructed area of buildings as a function of the building use and the construction period.

The quantity of material contained in the elements of buildings (e.g., walls, roofs, floors) evolved with construction periods. Figure 7 shows the evolution of the stock ratio of materials contained in the $\mathrm{CH}$ building elements of the Île-de-France region; details for the other building uses are given in Appendix C, Figure A2. A global view of the image shows that around $95 \%$ of the total weight of the buildings is contained in the load-bearing structure, that is to say, the foundations, low floors, intermediate floors, walls, and roof. Of all the structural elements of $\mathrm{CH}$, the most weighted are the intermediate floors and the exterior walls. For $\mathrm{CH}$ constructed before 1945, the exterior walls are the heaviest part of the buildings, at around $40 \%$ of the total building weight, followed by the intermediate floors ( $\approx 33 \%$ ); nevertheless, after the year 1945, the intermediate floors became the heaviest part of the buildings, increasing to a weight of around $60 \%$ of the total weight of the building. The weights of the floors and foundations increased too; its augmentation was understood by the increase in the weight of the intermediate floor, therefore a need for substantial foundations. 


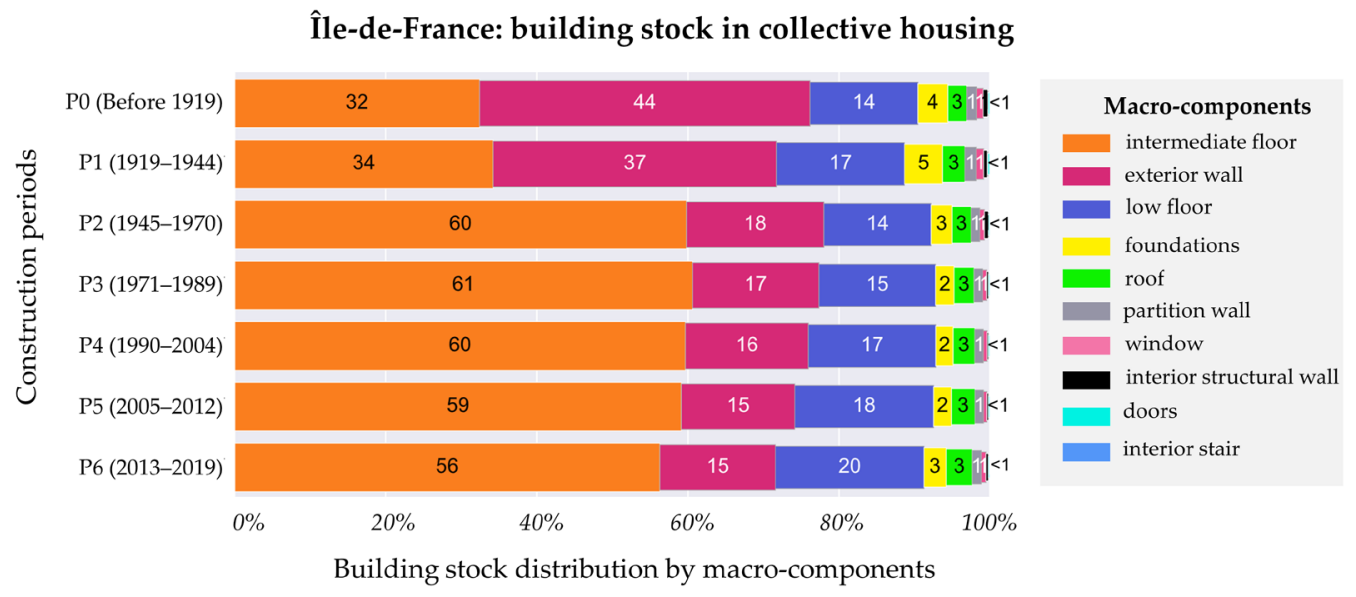

Figure 7. Building stock distribution and evolution for collective housing, segmented by the construction period and building macro-component composition.

\subsection{Extrapolation for Residential Buildings}

Knowing the strata rates for the sample and the population, a weighting factor was calculated for each strata, then applied to the building level; it allowed that after extrapolation, the results obtained at the territory level were as precise as possible.

In the land files, the materials of the structural walls are described by a double code that expressed the probability of having one material or another; this probability is $50 / 50$. Only for an example and a pedagogical illustration (Figure 8), the materials were grouped into four broad categories: bricks, concrete, stone, and wood; the choice of one material was made, taking into account the 50/50 probability. For the study case, every material composition was evaluated independently; then, by applying the concepts developed in Section 2.2.5, the matrix with the adjustment factors was calculated. These factors were then transposed to the building level. Once the materials' masses were calculated, the sample-level results were multiplied by the factors, thus allowing us to obtain consistent and representative results at the territory level.

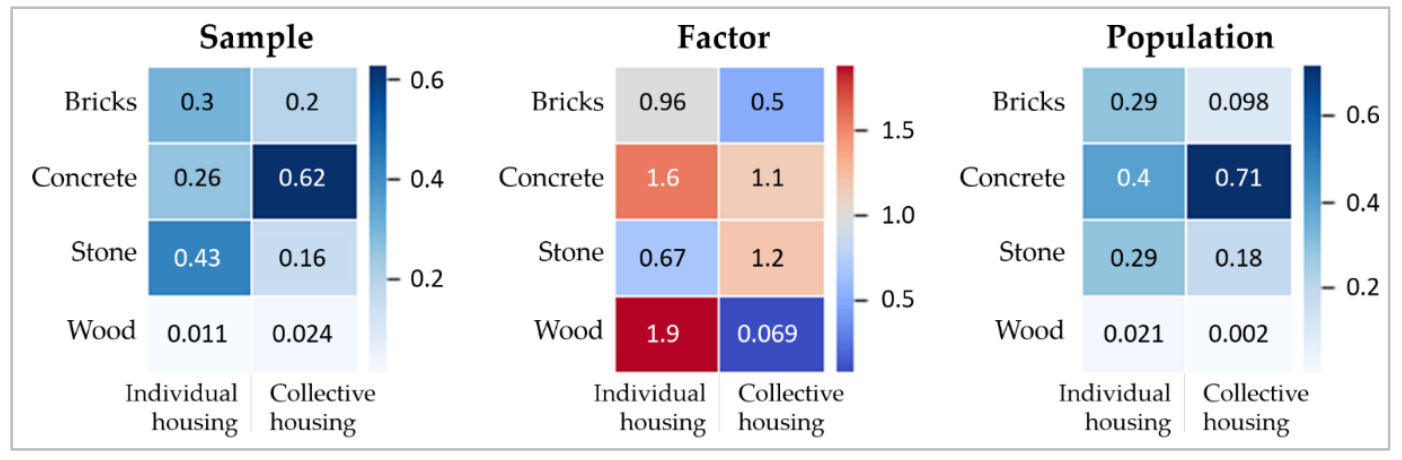

Figure 8. Estimation factor to extrapolate results from sample to population.

\subsection{Material Stock}

The current state of building material stock and its distribution according to the territorial division was estimated for the Île-de-France region. Results were calculated at the departmental level, then aggregated at the subregional and the regional level. Details were given for each territorial division, construction period, and building use; the stock results were also given according to the distribution of the elements in the buildings in Table S1 or according to the categories of materials (Table S2, Supplementary Materials). In the Supplementary Materials, Table S3 shows the average weight of materials stored in buildings according to constructed floor areas and building ground areas. 
The regional stock for the studied residential and non-residential building uses was estimated at 1382 megatons. It represents approximately 112 tons per capita or around 115 tons per $\mathrm{km}^{2}$. The distribution of stock by building use shows that the largest share of stock is cumulated in collective housing ( $53 \%$ or $731 \mathrm{Mt}$ ), followed by IH (30\% or $419 \mathrm{Mt}$ ), offices $(11 \%$ or $150 \mathrm{Mt})$, industrial buildings $(5 \%$ or $74 \mathrm{Mt})$, and finally education buildings $(<1 \%$ or $8 \mathrm{Mt})$. Concerning the distribution of the stock by subregions, the GC is in the lead $(48 \%$ or $664 \mathrm{Mt})$, followed by the PC (36\% or $500 \mathrm{Mt})$, and finally Paris $(16 \%$ or $218 \mathrm{Mt})$. The total inert stock represents on average $93 \%$ of the total stock for the residential sector and $94 \%$ for the non-residential sector.

Regarding the building stock distribution by construction period, $48 \%$ of the existing stock was built more than 50 years ago, that is to say, before the 1970s. For this group of buildings, we can distinguish three distinctive periods: (1) before 1919, (2) $\geq 1919$ to $<1945$, and finally $(3) \geq 1945$ and $\leq 1970$. The buildings constructed before $1919,17.5 \%$ of the total building stock, are mainly individual houses, although this period was also marked by the appearance of the first collective buildings. Individual houses from this period can present a wide variety of construction methods. Concerning collective buildings, this period includes, for example, the Haussmannian buildings and the HBM buildings (habitat bon marché or "cheap habitat"). Regarding the materials used in this period, we found mainly stone, wood, and gypsum. Still, the industrialization of building materials gave rise to the start of the homogenization of construction systems and the utilization of manufactured materials, such as iron, industrial bricks, and cement. The period between 1919 and 1945 was marked by a slowdown in construction and the destruction of buildings due to the two World Wars. The strong growth in demand for housing in the region during this period promoted the emergence of collective housing buildings that were established, particularly, in the suburbs of Paris. The period between 1945 and 1970 was marked by constructions made to meet strong demand for housing. Construction methods also continued to follow homogenization due to construction regulations, new technologies, and construction processes; thus, concrete became the material of choice; it was promoted by engineers who developed the filler blocks and formwork systems that allowed the heavy prefabrication of building elements. During this period, high-rise buildings emerged. The buildings constructed after 1970 were marked by the first oil shock of 1973, representing an inflection point between the construction of towers and bars of the previous period and a political program to reduce energy consumption. Construction techniques diversified; nevertheless, two significant trends, which can be complementary, developed: (1) the standardization of industrialization techniques in response to normative and regulatory demands and (2) singular construction systems and solutions oriented to better integrate the building into its urban, social, or environmental context. The distribution of materials are shown in Sankey diagrams in Appendix C, Figures A3 and A4.

The material categories in successive order of their importance by quantity are concrete and stone, gypsum, ceramic, brick, low adjuvanted wood, roofing tiles, windows, metals, and insulation; the concrete and stone category remains the most important material category. It contributes around $85 \%$ to the overall stock of material. More information in the tables of Supplementary Materials gives the stock distribution by subregion, construction period, building use, and stock by material categories.

\subsection{Material Flows}

The Sankey diagrams in Figure 9 illustrate material flows between these nodes: total, subregions, building use, construction period, and finally, categories of secondary resources. The flow results for the residential sector only relate to the construction period between 1945 and 1970; for the result of flows for the non-residential sector, all construction periods were included. The distribution of flows illustrated in Figure 9a shows the ratio of concrete and stone flows over the other flows. Figure $9 \mathrm{~b}$ shows the amount of secondary resource flows other than concrete and stone in detail. 


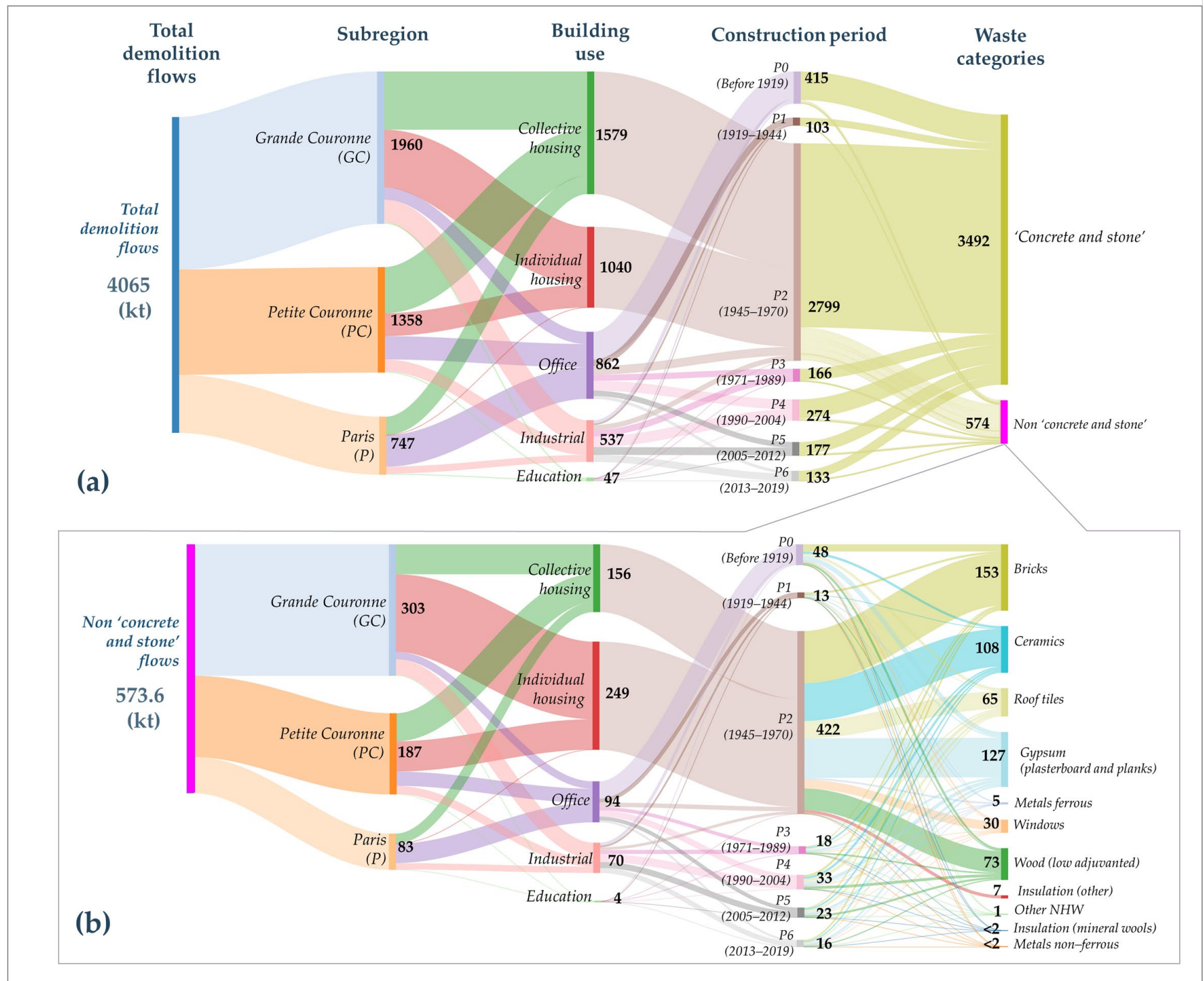

Figure 9. Île-de-France building material flows by waste categories. (a) Total demolition flows for Île-de-France region, distributed by subregion, building use, construction period and waste category. (b) Detail in the total other than 'concrete and stone' demolition flows, segmented by subregion, building use, construction period and waste category.

The total flows generated in the Île-de-France region were estimated at 4065 kilotons per year (all details in Supplementary Materials). In addition, Figure 9 shows that demolition flows from the residential sector are twice as high as those from the nonresidential sector. The construction period that generated the most quantity of secondary resources was the period that included buildings built between 1945 and 1970; it represents nearly $75 \%$ of the total flows generated. Figure 9 a shows that wastes are mainly composed of concrete and stone, as this category accounts for $86 \%$ of the total flows. Figure $9 \mathrm{~b}$ shows that, for flows other than concrete and stone, other categories of wastes are strongly present, such as brick, tiles, gypsum, or even wood. Nevertheless, there are categories of materials with lower amounts of presence in buildings, such as metals, insulation, and windows.

The subregions in Île-de-France have different urban characteristics. For example, Paris is a territory with a density within its urbanized area almost three times higher than the PC or even nearly nine times higher than the GC. Figure 10 compares the flow of materials per inhabitant by department and by subregion. At the regional level, the total demolition flows were estimated at $4065 \mathrm{kt}$ or $0.33 \mathrm{t} /$ capita; GC contributes around $48 \%$ of these flows, followed by PC with about 33\%, then Paris with approximately $18 \%$. 
Regarding flows per capita, GC produces $25 \%$ more flows than PC and only $3 \%$ more than Paris. Looking at the flows by department, the departments that produce the most flows per inhabitant are found in the north of the region: Seine-Saint-Denis, Val-d'Oise, and Hauts-de-Seine, while those that produce the most are in the center and south of the region: Essonne, Paris, and Yvelines; the Seine-et-Marne and Val-de-Marne departments in the east have an average flow production of $3.09 \mathrm{t} /$ capita. Concrete and stone remain the most produced waste category, with around $85 \%$ of the total flow produced. The production of flows other than concrete and stone s homogeneous in the departments evaluated.

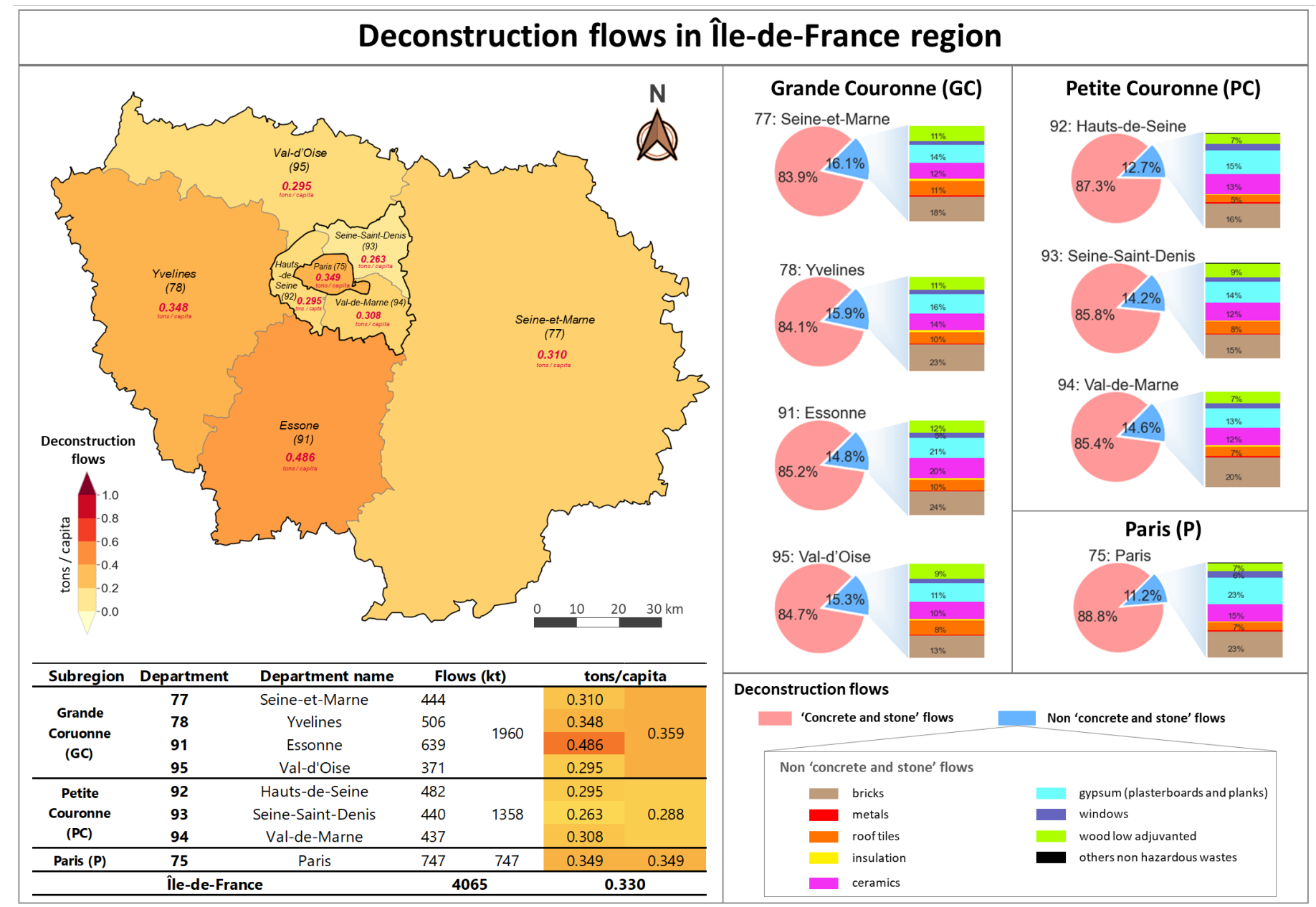

Figure 10. Waste flows per capita at different spatial scales and rates of waste categories.

\subsection{Relationship between Urbanization, Material Stock, and Demolition Flows}

In Figure 11, each point on the curve corresponds to the departmental level results; graphics show a correlation between the degree of urbanization, the population density, the material stock, and the waste flows. Results show a close correlation between the compactness of the city, that is to say, its degree of urbanization and the material density of flows and stock. As illustrated in Section 3.4, the population density in Paris is one of the highest in the world, and Paris is also the heaviest city in terms of building stock with more than 100 kilotons of material stock per capita. The departments with the lowest material density are at the north of Paris, where we find the highest population per built area. 


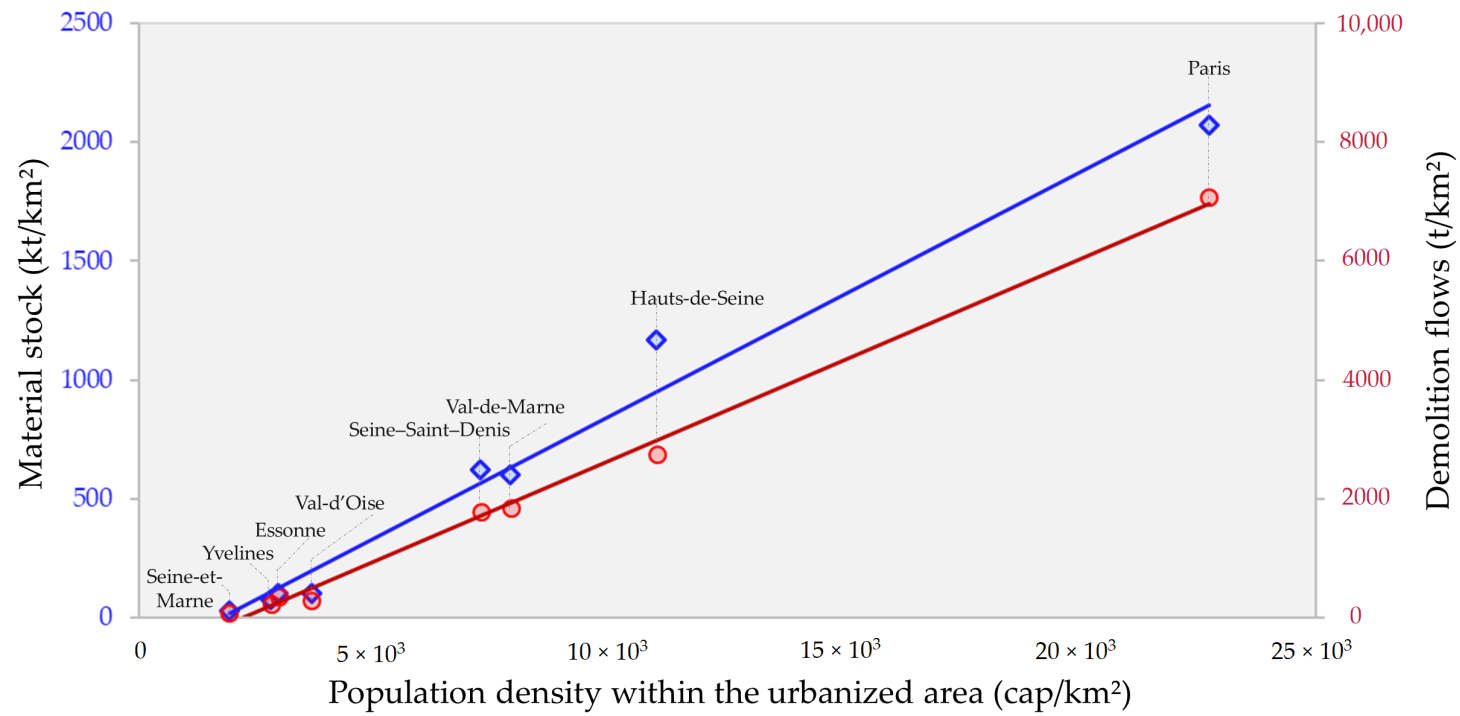

Figure 11. Correlation between the material stock (blue) and demolition flows (red) and the urbanization degree by department of the Île-de-France region.

\section{Discussion}

The characterization of the building stock of a territory is a departure point to understand the metabolism of this territory because the characteristics, nature, quantity, and quality of materials and products that make up the stock determine in large part other components of the metabolism, such as the identification of secondary resource deposits. This study results show that it is possible to characterize the material composition of the French building stock and the flows generated, due, for example, to demolitions, by combining open databases, bibliographic sources, and expert knowledge. Considerable efforts were made to construct the catalog of typical macro-components given the availability of data concerning the building's materiality, especially for non-residential buildings.

\subsection{Comparison with Previous Studies}

The comparison of the results with other studies was not obvious because the methodologies nor the methods used for calculating the material stock or flows were not the same. Nevertheless, stock density, considered a relevant index for comparing urban mines and potential secondary resources [41], could be used to obtain an overview of the stock and the deposit compared to other cities. The stock- and material-flow results obtained were compared with several analyses carried out for the Île-de-France.

Regarding the stock, Ref. [84] studied the flows for the Île-de-France region with a bottom-up approach based on 24 archetypes; the buildings studied are residential buildings plus non-residential buildings (commercial, industrial, and buildings for transport and storage). The stock results for the built sector gave $1.751 \mathrm{Mt}$ or $146 \mathrm{t} / \mathrm{cap}$. The distribution by subregion was, in t/cap, 197, 159, and 245 for P, PC, and GC, respectively. This study, in contrast, was based on 120 macro-components that combined and assembled described segments of the building stock. The study was applied to the residential sector and only three non-residential building uses, including the office, industrial, and education sectors. For all these uses (R and NR), a total stock of $1.382 \mathrm{Mt}$ or $112.2 \mathrm{t} /$ cap was obtained. The distribution per capita by subregion, in t/cap, gave 102, 106, and 122 for P, PC, and GC, respectively. The results were relatively close, but, as the studied sectors were not the same, a comparison of the total stock was not possible. Nevertheless, a comparison of the stock for the residential sector can be made. Ref. [84] obtained 495,823 Mt for IH and 907,146 Mt for $\mathrm{CH}$; with the BTP-flux model, we calculated 419,264 Mt for IH and $731,121 \mathrm{Mt}$ for $\mathrm{CH}$. For $\mathrm{IH}$, results were relatively close; on the other hand, for $\mathrm{CH}$, the difference between the results was around $24 \%$. One of the limits of our study was that 
the quantity of stock in the infrastructures was underestimated because there is a lack of data for this buildings' lot; therefore, building basements that can include large surfaces with underground parking, especially for $\mathrm{CH}$ and offices, were not considered. At the moment, the model only calculates materials for foundations, taking into account the assumption that under all structural walls, there are strip footings. According to [84], 22\% of the building stock is in the buildings' basement, so our results were consistent. To better understand these differences, the presented model can be completed with data relating to these elements of the buildings.

Regarding waste flows from building demolitions, various studies were developed for the region; for example, studies based on surveys, economic data, and waste production ratios were carried out by $[82,85,86]$. They respectively obtained results of the order of 7.07, 8.4, and 8.4 Mt of demolition flux for 2000, 2010, and 2015, respectively. These studies also estimated the percentage of flows by category of inert, non-inert, and hazardous waste. The study carried out by [61] for material flows in 2013 used a bottom-up approach, and it calculated demolition flows according to the floor surfaces and material intensities by building archetype; material intensities were adapted from [87]. The characterization model of the built stock is explained in [84]. The results of [61] gave quantities of demolition wastes by type of material; the quantity of flow was estimated on average at $9650 \mathrm{Mt}$ or $0.805 \mathrm{t} /$ cap for the Île-de-France region; at the subregional level, the waste flows were estimated on average at $0.55,0.9$, and 0.85 for P, PC, and GC respectively. The BTP-flux model estimated the demolition waste at $4065 \mathrm{Mt}$ or $0.33 \mathrm{t} / \mathrm{cap}$, and wastes are distributed over P, PC, and GC at $0.349,0.288$, and $0.359 \mathrm{t} / \mathrm{cap}$, respectively. The present model gave waste flow details by building use, construction period, department or subregion, and waste categories. Although the results obtained with our method were lower than results from cited articles and reports, this underestimation is because demolition flows depend on the material stock, and the modeling underestimates materials in infrastructures; nevertheless, the BTP-flux model is consistent and transparent.

\subsection{Model Utility and Result Application}

This research proposed a macro-components-based, bottom-up modeling approach that allowed a modular description of the products and materials in the built stock. This approach enabled the description of buildings quickly and with little human intervention with the objective of carrying out several simulations (e.g., MSA, MFA, LCA). BTP-flux structure gives a range of possibilities for systematically evaluating the building stocks at different territorial scales; if good quality data is available, then results may be valid on a finer scale. The model also allows the implementation of assessment at different time scales. The model was built on three main national databases: the cadastral database BD-TOPO, the property tax fichiers fonciers files, and the energy performance diagnostics EPD. The geospatial cross-referencing of databases allowed us to obtain a sample of buildings; and, that, with the coupling of the catalog of macro-components allowed us to obtain a sample of buildings with richly described materiality. All the assessments were carried out on this sample, then extrapolated to the scale of the territory. This research showed that it was possible to combine data not necessarily dedicated to identifying the building's materiality to develop an MFA. Data, such as cadastral data, gave information on the geometry of buildings and land data, and energy performance data provided details on the building's materiality and performance. The data-crossing method allowed rapid incorporation of new georeferenced data and data updates, linking other databases to increase the level of detail of the building descriptions and also to compare the data in the databases and improve their reliability. Considering the developed data infrastructure, we can extract building data at different territorial scales and on other territories of France.

Even if the model used static data, it provided empirical results on the building stock characteristics and the waste flows generated from demolitions (in Île-de-France for this study case). The evaluation was made at the department scale, then aggregated at the subregional level, and finally at the regional level. The study provided results based on the 
urban characteristics, such as the degree of urbanization and the density of territories, that can strongly influence the composition of the stock and flows.

From an application point of view, our results can be useful for strategic planning of waste management and potential secondary resources where the goal is to retain the value of materials as much as possible during value chains (building demolition; materialsseparation, collection, sorting, grouping, treatment, re-utilization, recycling). In particular, a better understanding of a territory's building material stock and demolition flows should allow better management of resources and lessen environmental impacts. In addition, the estimation of potential secondary resource flows - waste flows-directs them towards the various reuse and recycling sectors and anticipates the capacity of transit, massification, sorting, and existing recycling facilities.

BTP-flux allows distribution and a spatial representation of stocks and flows and the anticipation of waste flows that urban or territorial operations could generate. Mapping material stocks and deposits can accelerate the exploration of secondary resource strategies more accurately. Public authorities and local authorities can, for example, develop secondary resource recovery channels, group together materials from demolitions and renovations on local reconditioning and storage platforms, and support the development of new economic lines. Urban planners can develop and implement reuse and recycling on short chains. Building stock managers can identify the potential for recovery to put in place adapted strategies. Moreover, building stakeholders can improve the use of resources available at the end of a building's life, facilitate and optimize waste collection, support secondary resource recovery channels, as well as carry out an inventory of their stock to assess the issues associated with the types of waste that might be generated during the renovation of their building stock.

For the reasons explained and because results allow the anticipation of demolition wastes and its application for CE strategy formulation, BTP-flux can take advantage of local resources, especially the existing urban mine. The CE represents a tool for evolution in the construction sector; nevertheless, all stakeholders are called upon to act at different territorial scales. The idea is to stop seeing materials as waste, but rather as resources. In this context, this study proposed a detailed characterization of the categories of materials in the building stock and material flows resulting from demolitions.

\subsection{Limitations and Future Research}

\subsubsection{Data Availability}

The collection and processing of data can be one of the most restrictive steps, due to the time required to contact the actors and obtain the data, because, given the heterogeneity of the building stock, the number of actors to contact can take a long time. Then, the collected data is not always representative of the building stock; they are segmented and often incomplete. Consequently, the processing requires interdisciplinary knowledge. For this study, the studied sample was chosen by commodity; nevertheless, the sample size was representative of the assessed territory. In fact, it was not possible to obtain detailed information about materiality for every building in the population, nor was it possible to analyze buildings in a large area, one by one, because of the evaluation time required.

\subsubsection{Model}

The method based on macro-components allowed a continuous improvement on various points, such as details on building materiality, sizes of the buildings, categories of buildings assessed, and the demolition hypotheses. Additional research will be necessary to obtain data to improve the level of information of macro-components (for example, currently, they do not include information concerning the presence of hazardous materials, such as asbestos or lead) and to incorporate information on the non-studied building categories in this article, specifically non-residential buildings.

The model structure allows additional information on the quality of materials from the urban mine to be included in the future. The BTP-flux model allows tackling subjects 
other than the materiality of the building, such as the renovation of buildings and the environmental impacts linked to renovations; the method can also be extended to the evaluation of new construction and urban planning. Although the model and the presented results are static, the approach used is a prerequisite for dynamic studies [88], because the model infrastructure allows the association of detailed information or scenarios in the future dynamics of stocks and flows.

\subsubsection{Flow Estimation}

Although the calculation of masses and the estimation of flows mainly for the building envelope and the load-bearing structure were made taking into account the real geometry of the building, assumptions had to be formulated to complete lacking information concerning, for example, the interior division of buildings (e.g., partitioning walls). An alternate hypothesis about lifetime can change the calculated demolition flows. If we observe the Parisian building stock, we can see that a significant segment of buildings are older than 100 years, because buildings can be conserved longer than expected for architectural reasons. The material flows were calculated based on generic demolition rates transposed to the ratios of existing buildings by segment; it may turn out that this hypothesis does not apply to certain territories given the urban characteristics or socio-economic parameters. Other ways of estimating flows should be explored.

\subsubsection{Uncertainties}

Accurate estimation of the distribution, quantity, and composition of waste is essential for efficient resource management, but it can represent a challenge [12]; consequently, the robustness of MFA models should be assessed. The proposed BTP-flux model was based on a series of steps that combined different research fields, so the uncertainty analysis was challenging. To verify the validity of our model initially, we opted to compare our results with previous studies in the region, which provided a first glimpse of the consistency of the results (see Section 4.1). Nevertheless, the results contain a degree of uncertainty that could come from the parameters and the assumptions retained for the model: for instance, from databases, from the definition of macro-components, from the buildings' dimensioning, from the assumptions to determine the demolition rates, and from the structure of the model itself (meta-uncertainties). A complete and systematic quantification of the uncertainties at the different stages of the model was beyond the scope of this study; nevertheless, they will be addressed in future research for the same project as part of its improvement and validation of results.

\section{Conclusions}

The main objective of this research was to improve the level of knowledge of the urban mine's materiality (nature, quantity), both at the level of the building stock and of the demolition flows. Although there are currently aggregated data about these flows (inert, hazardous, non-hazardous waste), these data are not enough to correctly manage increasingly scarce natural resources, and, at the same time, their exploitation generates strong environmental impacts.

In this context, this research proposed the BTP-flux model, a bottom-up macrocomponent-based model, allowing the building stock and flow characterization at several territorial scales through the high-level refinement of identification and classification of demolition wastes by taking account of 32 waste categories. The afore-mentioned, could, first of all, limit the demand for raw materials through the early identification of secondary resources that could be potentially recovered from demolitions; second, it could look forward to needs (for instance, land for installations, storage and classification platforms) and plan for optimal resource management. The main aspiration is to valorize, as well as possible, the resources present in the urban mine.

The BTP-flux model was applied to the Île-de-France region to estimate the stock and flows from demolition. Thanks to the bottom-up approach, results were presented 
by building segment (use and construction period) and at different spatial scales: interregional (eight departments), subregional ("couronnes"), and regional. The results showed that the stock and flow of materials are mainly concentrated in residential buildings and that the stock of materials is mainly concentrated in buildings' structural elements, thus responsible for the biggest share in demolition waste. It is important to highlight that structural wastes are mainly inert wastes, and consequently, the biggest share of the total wastes. Non-inert materials are stored principally in finishings, and, although the quantity of non-inert materials represents less than $10 \%$ of the total waste, its knowledge is not sufficient yet. This part of the stock merits further research to improve the quality and reliability of MFA models.

In brief, our results gave visibility on 12 principal types of demolition waste generated in the Île-de-France region and these subentities. In quantitative terms, the BTP-flux model estimated the stock in the region at 1382 megatons, distributed in 664, 500, and $218 \mathrm{Mt}$ for the Grande Couronne, Petite Couronne, and Paris, respectively. The demolition wastes were assessed at $4065 \mathrm{kt}$ or $0.33 \mathrm{t} / \mathrm{cap}$ annually for the region and estimated at $0.359,0.288$, and $0.349 \mathrm{t} / \mathrm{cap}$ for the Grande Couronne, Petite Couronne, and Paris, respectively.

Although the results obtained with our method were lower than results from cited articles and reports, this could be explained by some simplification in the model (basement area was neglected, for example). In perspective, limits of the model can be overridden by incorporating new data (for instance, on basement areas or regarding dangerous materials) or by validation with results coming for in situ studies and by quantitative or qualitative uncertainties analysis.

Supplementary Materials: The following are available online at https:/ /www.mdpi.com/article/ 10.3390/su132313159/s1: Table S1. Building stock distribution by macro-components; Table S2. Building stock distribution by material categories; Table S3. Building stock: Average weight of materials stored in buildings according to constructed floor areas and building ground areas; and Table S4. Demolition wastes by waste category, couronne, building use, and construction period.

Author Contributions: Conceptualization, S.L., M.L., A.A., G.H. and R.T.; methodology, S.L., M.L., R.T. and A.A.; software, A.A. and R.T.; validation, S.L., M.L., A.A. and R.T.; formal analysis, R.T.; investigation, A.A., R.T. and G.H.; resources, M.T., A.A. and R.T.; data curation, R.T. and M.T.; writing—original draft preparation, R.T.; writing—review and editing, R.T., A.A., G.H. and M.L.; visualization, R.T.; supervision, M.L. and S.L.; project administration, S.L.; funding acquisition, S.L. All authors have read and agreed to the published version of the manuscript.

Funding: The BTP-flux project was financed by the French Agency for Ecological Transition (ADEME) Île-de-France and the Scientific and Technical Center for Building (CSTB) and was carried out with the support of the Île-de-France region: agreement number 18IFC0153.

Institutional Review Board Statement: Not applicable.

Informed Consent Statement: Not applicable.

Data Availability Statement: BD-TOPO data can be founded here: https:/ /geoservices.ign.fr/bdtopo (accessed on 10 October 2021). Fichiers fonciers can be obtained from Cerema here: https:/ / datafoncier. cerema.fr/donnees/fichiers-fonciers (accessed on 10 October 2021). DPE data from Ademe can be obtained here: https: / /data.ademe.fr/datasets/dpe-france (accessed on 10 October 2021). The French National Addressed Database can be founded here: https://geo.api.gouv.fr/adresse (accessed on 10 October 2021).

Acknowledgments: The authors thank all the funders and supporters of the BTP-flux project. The authors also thank Antoine Breitwiller, Emilie Gully, Pascal Schetelat, and colleagues from the Scientific and Technical Center for Building (CSTB) for their contributions. The research presented in this article is part of the research work of the Ph.D. thesis of the first author planned from 2018-2022; this research is funded by the CSTB. The first author also thanks the Palladio Foundation for the support.

Conflicts of Interest: The authors declare no conflict of interest. 


\section{Appendix A}

Table A1. TyPy sources coming from literature. $\mathrm{CH}$ : collective housing, R: residential, NR: non-residential.

\begin{tabular}{|c|c|c|c|c|}
\hline Reference & Geographic Boundaries & Period under Study & Buildings Use & Number of Building Type \\
\hline [89] & France & Before 2000 & $\mathrm{R}$ & 26 \\
\hline [90] & Paris suburbs & Before 1920-1940 & $\mathrm{CH}$ & l \\
\hline [91] & Paris & 1945-1974 & $\mathrm{R}$ and $\mathrm{NR}$ & 6 \\
\hline [92] & France & 1850-2014 & $\mathrm{R}$ & 40 \\
\hline [93] & France & Before 1948 & $\mathrm{R}$ & 19 \\
\hline [94] & France & 1950-1984 & $\mathrm{CH}$ & 10 \\
\hline [95] & France & 1949-1981 & $\mathrm{CH}$ & 4 \\
\hline [96] & Paris & Before $1800-2000$ & $\mathrm{CH}$ & 13 \\
\hline [97] & France & Before 1948 & $\mathrm{R}$ & 7 \\
\hline [98] & France & Before 1918 & $\mathrm{R}$ & 10 \\
\hline [99] & France & Before 1914-2000 & $\mathrm{R}$ & 46 \\
\hline [100] & France & 1947-1997 & $\mathrm{R}$ & / \\
\hline [101] & Saint-Denis (Paris North) & 1850-1914 & $\mathrm{R}$ & 20 \\
\hline CSTB studies on building stock & France & Before 1914-2020 & $\mathrm{R}$ and $\mathrm{NR}$ & / \\
\hline
\end{tabular}

\section{Appendix B}

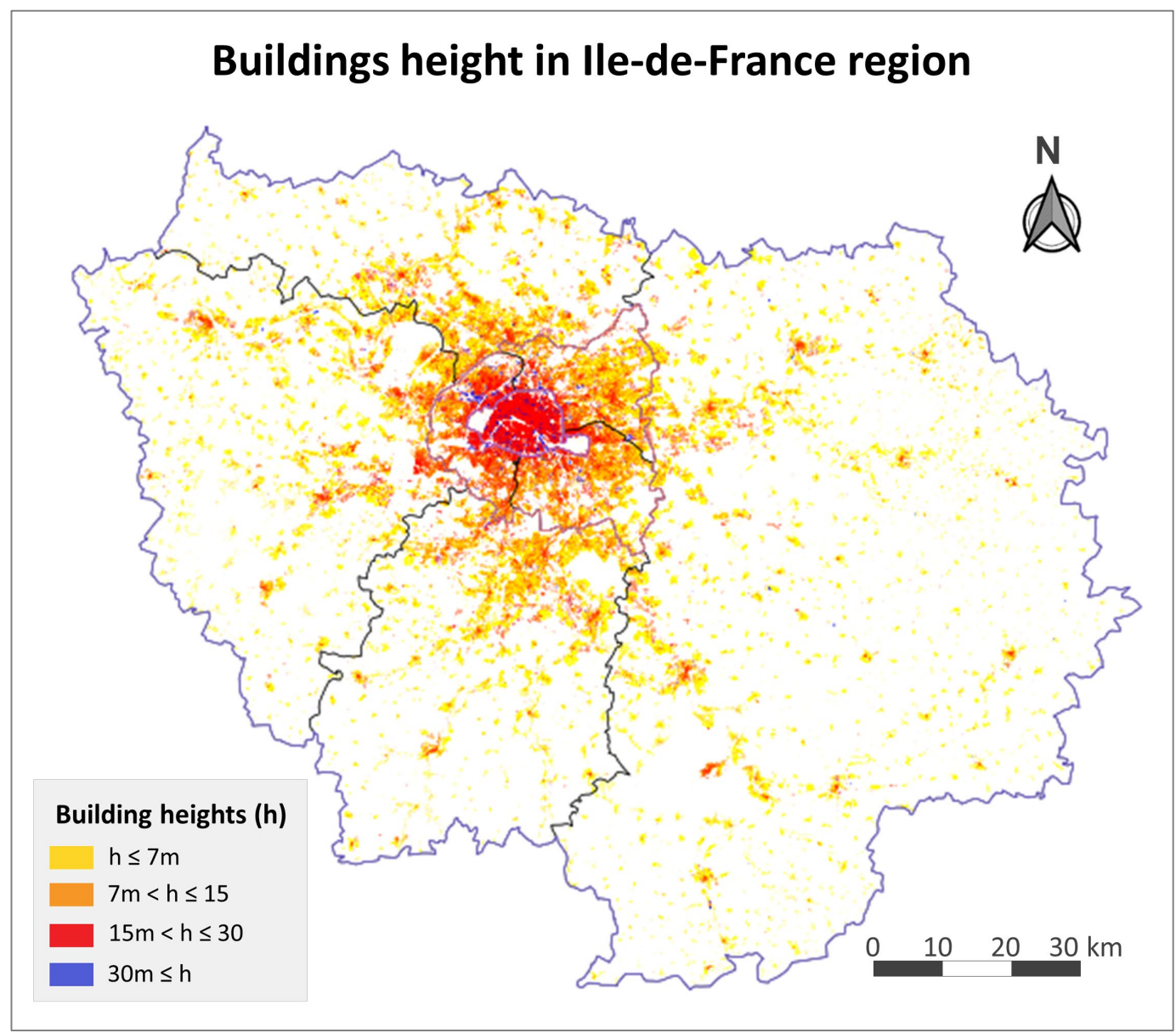

Figure A1. Building height groups. The plotted results correspond only to the buildings generated by data crossing and present in the BDNB. 


\section{Appendix C}

île-de-France: Building stock by building use and construction period
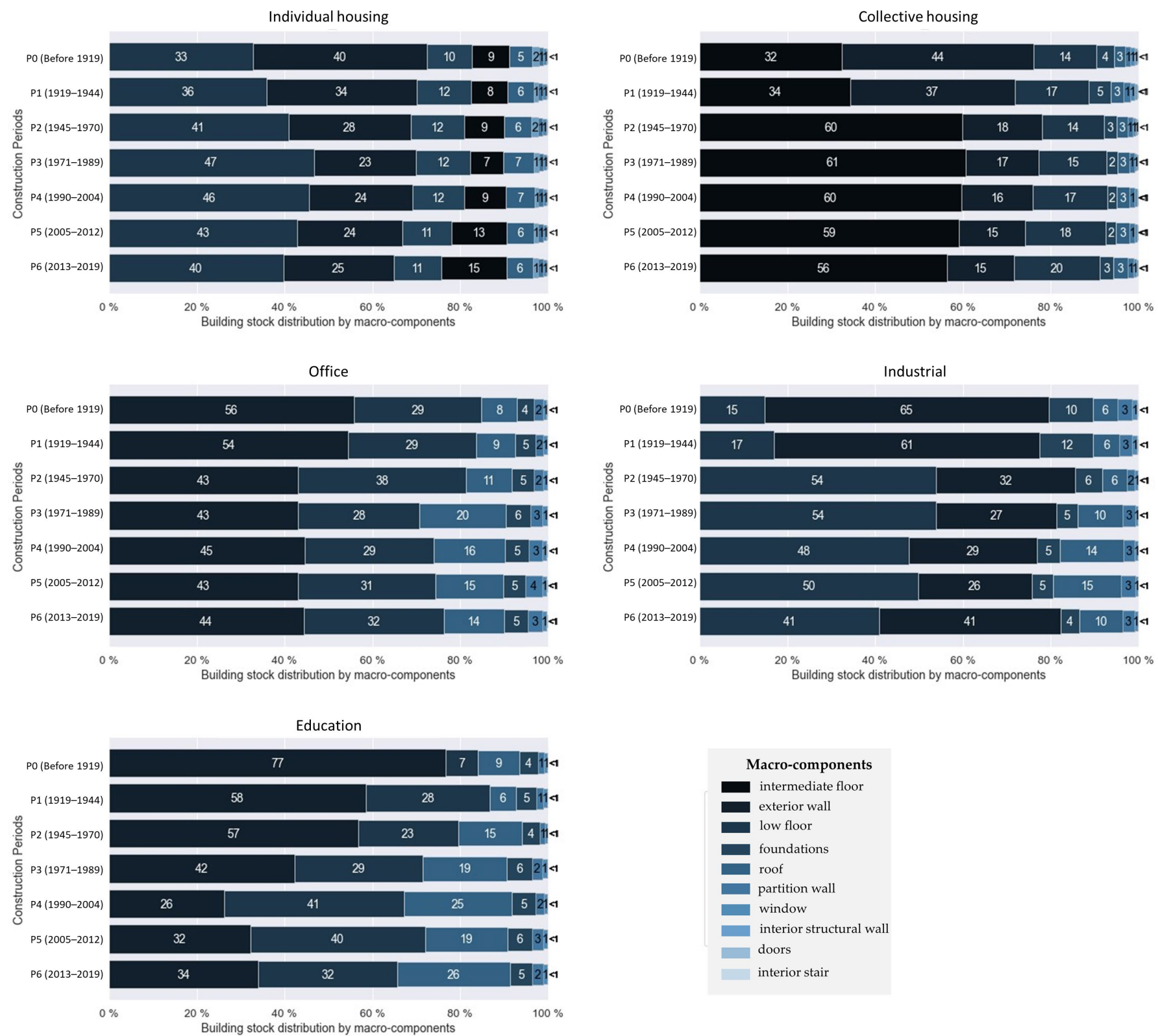

Figure A2. Evolution of building material composition by macro-components, construction period and building use for the Île-de-France region. 


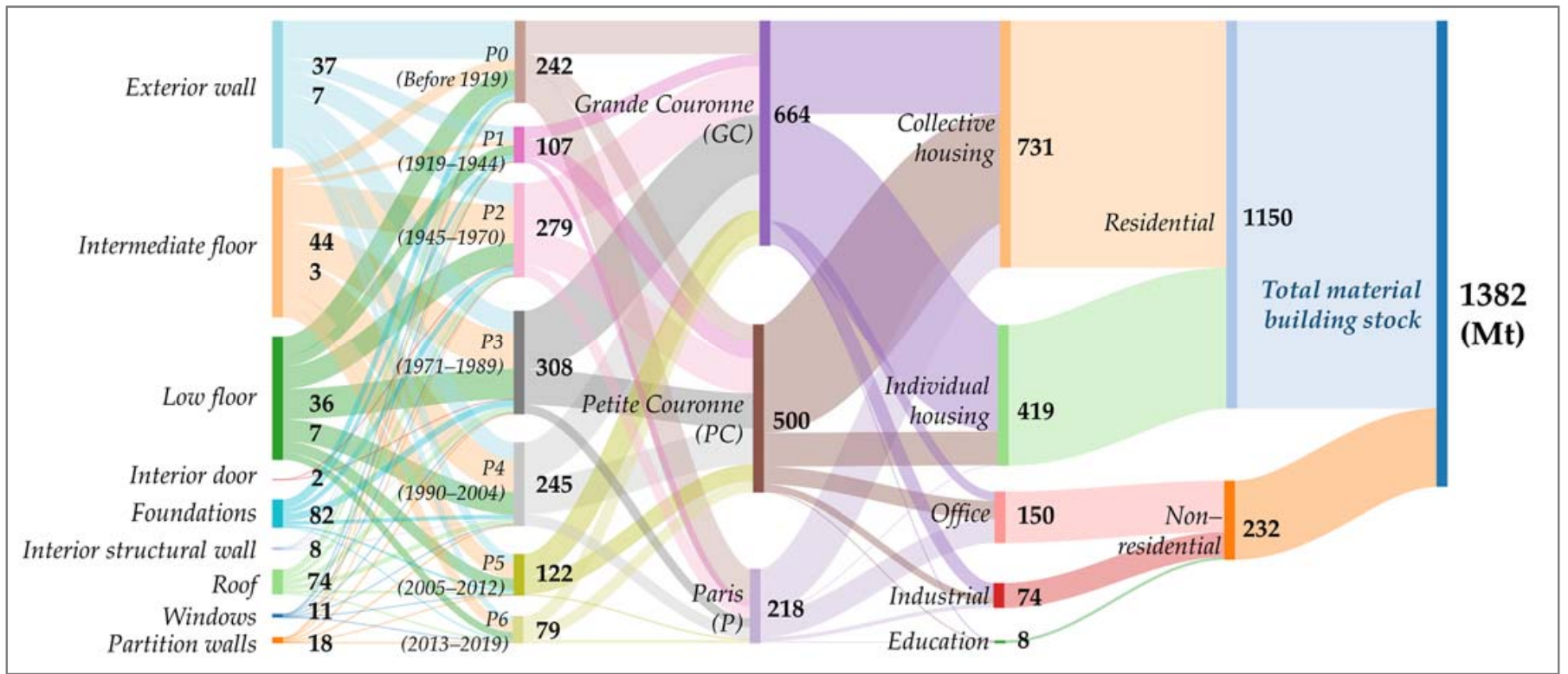

Figure A3. Île-de-France: distribution of stocked materials by building element composition for every construction period and building use for the three suburban regions: Paris (P), Petite Couronne (PC), and Grande Couronne (GC).

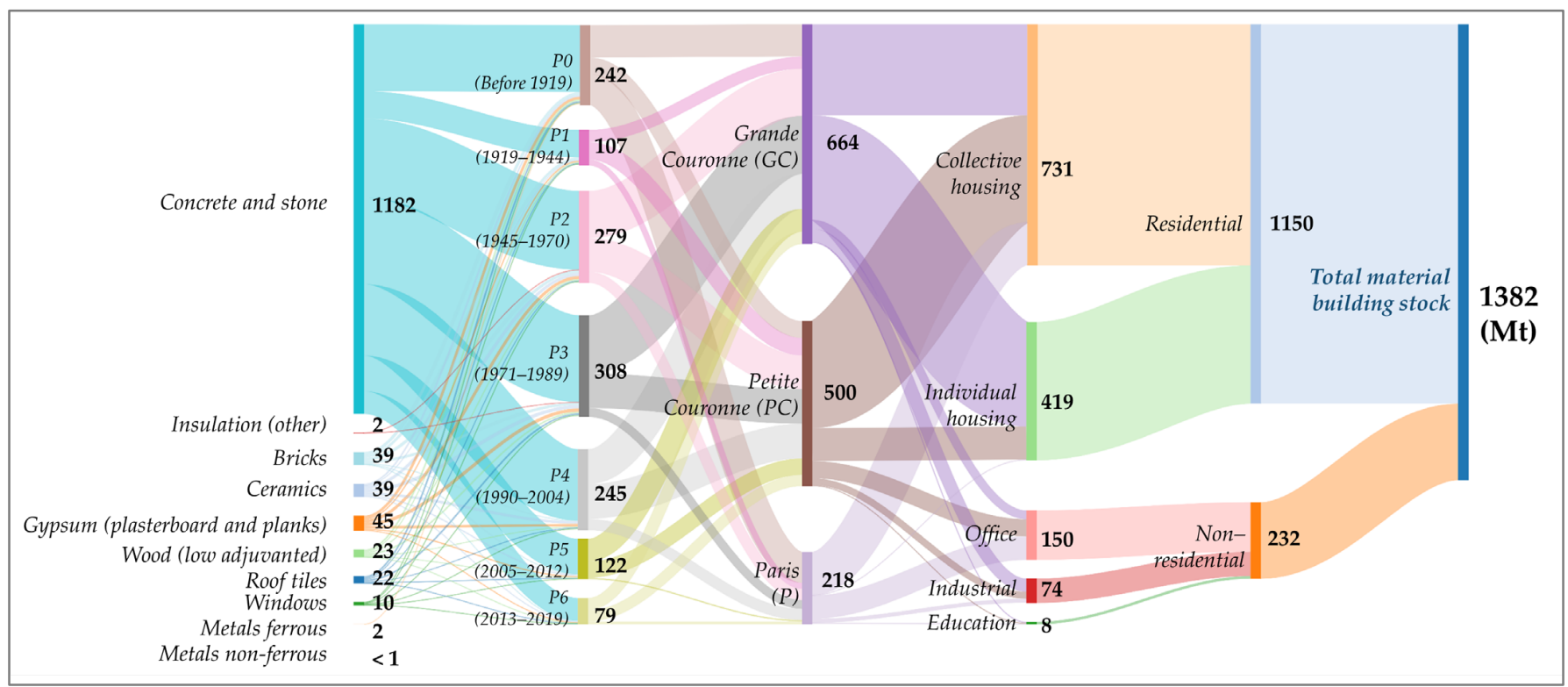

Figure A4. Île-de-France building material stock by material categories for every construction period and building use for the three suburban regions: Paris (P), Petite Couronne (PC), and Grande Couronne (GC).

\section{References}

1. United Nations. World Urbanization Prospects: The 2018 Revision. 2018. Available online: https:/ / population.un.org/wup/ Publications / (accessed on 18 June 2020).

2. Ellen Macarthur Foundation. Circular Economy in Cities: Project Guide. 2019. Available online: https://www. ellenmacarthurfoundation.org/assets/downloads/CE-in-Cities-Project-Guide_Mar19.pdf (accessed on 24 March 2021).

3. Lanau, M.; Liu, G. Developing an Urban Resource Cadaster for Circular Economy: A Case of Odense, Denmark. Environ. Sci. Technol. 2020, 54, 4675-4685. [CrossRef]

4. Augiseau, V.; Barles, S. Studying construction materials flows and stock: A review. Resour. Conserv. Recycl. 2017, 123, 153-164. [CrossRef]

5. Rosado, L.; Kalmykova, Y.; Patrício, J. Urban metabolism profiles. An empirical analysis of the material flow characteristics of three metropolitan areas in Sweden. J. Clean. Prod. 2016, 126, 206-217. [CrossRef] 
6. Göswein, V.; Silvestre, J.D.; Habert, G.; Freire, F. Dynamic Assessment of Construction Materials in Urban Building Stocks: A Critical Review; American Chemical Society: Washington, DC, USA, 2019; Volume 53, pp. 9992-10006.

7. Menegaki, M.; Damigos, D. A review on current situation and challenges of construction and demolition waste management. Curr. Opin. Green Sustain. Chem. 2018, 13, 8-15. [CrossRef]

8. Ajayi, S.O.; Oyedele, L.O. Policy imperatives for diverting construction waste from landfill: Experts' recommendations for UK policy expansion. J. Clean. Prod. 2017, 147, 57-65. [CrossRef]

9. Villoria Sáez, P.; Osmani, M. A diagnosis of construction and demolition waste generation and recovery practice in the European Union. J. Clean. Prod. 2019, 241, 118400. [CrossRef]

10. Yuan, H.; Shen, L. Trend of the research on construction and demolition waste management. Waste Manag. 2011, 31, 670-679. [CrossRef] [PubMed]

11. Tam, V.W.; Li, J.; Cai, H. System dynamic modeling on construction waste management in Shenzhen, China. Waste Manag. Res. 2014, 32, 441-453. [CrossRef]

12. Ma, M.; Tam, V.W.Y.; Le, K.N.; Li, W. Challenges in current construction and demolition waste recycling: A China study. Waste Manag. 2020, 118, 610-625. [CrossRef]

13. Petit-Boix, A.; Leipold, S. Circular economy in cities: Reviewing how environmental research aligns with local practices. J. Clean. Prod. 2018, 195, 1270-1281. [CrossRef]

14. UNEP Resource Efficiency and Climate Change: Material Efficiency Strategies for a Low-Carbon Future. 2020. Available online: https: / / www.resourcepanel.org/reports/resource-efficiency-and-climate-change (accessed on 25 March 2021).

15. Ministère de la Transition Écologie. The Anti-Waste Law in the Dailylives of the French People: What Does That Mean in Practice? 2020. Available online: https:/ / circulareconomy.europa.eu/platform/sites/default/files/anti-waste_law_in_the_daily_lives_ of_french_people.pdf (accessed on 24 March 2021).

16. Alnajem, M.; Mostafa, M.M.; Elmelegy, A.R. Mapping the first decade of circular economy research: A bibliometric network analysis. J. Ind. Prod. Eng. 2020, 38, 29-50. [CrossRef]

17. Pomponi, F.; Moncaster, A. Circular economy for the built environment: A research framework. J. Clean. Prod. 2017, 143, 710-718. [CrossRef]

18. Schiller, G.; Müller, F.; Ortlepp, R. Mapping the anthropogenic stock in Germany: Metabolic evidence for a circular economy. Resour. Conserv. Recycl. 2017, 123, 93-107. [CrossRef]

19. Pauliuk, S.; Wang, T.; Müller, D.B. Moving toward the circular economy: The role of stocks in the Chinese steel cycle. Environ. Sci. Technol. 2012, 46, 148-154. [CrossRef]

20. Domingo, N.; Batty, T. Construction waste modelling for residential construction projects in New Zealand to enhance design outcomes. Waste Manag. 2021, 120, 484-493. [CrossRef]

21. Schiller, G.; Gruhler, K.; Ortlepp, R. Continuous Material Flow Analysis Approach for Bulk Nonmetallic Mineral Building Materials Applied to the German Building Sector. J. Ind. Ecol. 2017, 21, 673-688. [CrossRef]

22. Van der Voet, E.; Kleijn, R.; Huele, R.; Ishikawa, M.; Verkuijlen, E. Predicting future emissions based on characteristics of stocks. Ecol. Econ. 2002, 41, 223-234. [CrossRef]

23. Cao, Z.; Shen, L.; Zhong, S.; Liu, L.; Kong, H.; Sun, Y. A Probabilistic Dynamic Material Flow Analysis Model for Chinese Urban Housing Stock. J. Ind. Ecol. 2018, 22, 377-391. [CrossRef]

24. Ellen Macarthur Foundation. The Built Environment: Two Key Circular Investment Opportunities for a Resilient and Low-Carbon Economic Recovery. Available online: https:/ / www.ellenmacarthurfoundation.org/our-work/activities/covid-19/the-builtenvironment (accessed on 24 March 2021).

25. Stephan, A.; Athanassiadis, A. Towards a more circular construction sector: Estimating and spatialising current and future non-structural material replacement flows to maintain urban building stocks. Resour. Conserv. Recycl. 2018, 129, $248-262$. [CrossRef]

26. Müller, E.; Hilty, L.M.; Widmer, R.; Schluep, M.; Faulstich, M. Modeling metal stocks and flows: A review of dynamic material flow analysis methods. Environ. Sci. Technol. 2014, 48, 2102-2113. [CrossRef]

27. Lanau, M.; Liu, G.; Kral, U.; Wiedenhofer, D.; Keijzer, E.; Yu, C.; Ehlert, C. Taking Stock of Built Environment Stock Studies: Progress and Prospects. Environ. Sci. Technol. 2019, 53, 8499-8515. [CrossRef]

28. Röck, M.; Baldereschi, E.; Verellen, E.; Passer, A.; Sala, S.; Allacker, K. Environmental modelling of building stocks-An integrated review of life cycle-based assessment models to support EU policy making. Renew. Sustain. Energy Rev. 2021, 151, 111550. [CrossRef]

29. Athanassiadis, A. Economie Circulaire Dans le Secteur de la Construction à Bruxelles: État des Lieux, Enjeux et Modèle à Venir. 2017. Available online: http:/ / www.circulareconomy.brussels/wp-content/uploads/2017/10/RAP_2017_Economie-CirculaireConstruction.pdf (accessed on 7 January 2019).

30. Schiller, G.; Bimesmeier, T.; Pham, A.T.V. Method for quantifying supply and demand of construction minerals in urban regions-A case study of hanoi and its Hinterland. Sustainability 2020, 12, 4358. [CrossRef]

31. Tanikawa, H.; Fishman, T.; Okuoka, K.; Sugimoto, K. The weight of society over time and space: A comprehensive account of the construction material stock of Japan, 1945-2010. J. Ind. Ecol. 2015, 19, 778-791. [CrossRef]

32. Mesta, C.; Kahhat, R.; Santa-Cruz, S. Geospatial Characterization of Material Stock in the Residential Sector of a Latin-American City. J. Ind. Ecol. 2019, 23, 280-291. [CrossRef] 
33. Hu, M.; van der Voet, E.; Huppes, G. Dynamic Material Flow Analysis for Strategic Construction and Demolition Waste Management in Beijing. J. Ind. Ecol. 2010, 14, 440-456. [CrossRef]

34. Han, J.; Chen, W.Q.; Zhang, L.; Liu, G. Uncovering the Spatiotemporal Dynamics of Urban Infrastructure Development: A High Spatial Resolution Material Stock and Flow Analysis. Environ. Sci. Technol. 2018, 52, 12122-12132. [CrossRef] [PubMed]

35. Wang, H.; Chen, D.; Duan, H.; Yin, F.; Niu, Y. Characterizing urban building metabolism with a 4D-GIS model: A case study in China. J. Clean. Prod. 2019, 228, 1446-1454. [CrossRef]

36. Miatto, A.; Schandl, H.; Forlin, L.; Ronzani, F.; Borin, P.; Giordano, A.; Tanikawa, H. A spatial analysis of material stock accumulation and demolition waste potential of buildings: A case study of Padua. Resour. Conserv. Recycl. 2019, 142, 245-256. [CrossRef]

37. Heeren, N.; Fishman, T. A database seed for a community-driven material intensity research platform. Sci. Data 2019, 6, 23. [CrossRef]

38. Yang, D.; Guo, J.; Sun, L.; Shi, F.; Liu, J.; Tanikawa, H. Urban buildings material intensity in China from 1949 to 2015. Resour. Conserv. Recycl. 2020, 159, 104824. [CrossRef]

39. Schiller, G.; Miatto, A.; Gruhler, K.; Ortlepp, R.; Deilmann, C.; Tanikawa, H. Transferability of Material Composition Indicators for Residential Buildings: A Conceptual Approach Based on a German-Japanese Comparison. J. Ind. Ecol. 2019, 23, 796-807. [CrossRef]

40. Tanikawa, H.; Hashimoto, S. Urban stock over time: Spatial material stock analysis using 4d-GIS. Build. Res. Inf. 2009, 37, 483-502. [CrossRef]

41. Kleemann, F.; Lederer, J.; Rechberger, H.; Fellner, J. GIS-based Analysis of Vienna's Material Stock in Buildings. J. Ind. Ecol. 2017, 21, 368-380. [CrossRef]

42. Gontia, P.; Nägeli, C.; Rosado, L.; Kalmykova, Y.; Österbring, M. Material-intensity database of residential buildings: A case-study of Sweden in the international context. Resour. Conserv. Recycl. 2018, 130, 228-239. [CrossRef]

43. Ortlepp, R.; Gruhler, K.; Schiller, G. Material stocks in Germany's non-domestic buildings: A new quantification method. Build. Res. Inf. 2016, 44, 840-862. [CrossRef]

44. Schebek, L.; Schnitzer, B.; Blesinger, D.; Köhn, A.; Miekley, B.; Linke, H.J.; Lohmann, A.; Motzko, C.; Seemann, A. Material stocks of the non-residential building sector: The case of the Rhine-Main area. Resour. Conserv. Recycl. 2017, 123, 24-36. [CrossRef]

45. Arora, M.; Raspall, F.; Cheah, L.; Silva, A. Residential building material stocks and component-level circularity: The case of Singapore. J. Clean. Prod. 2019, 216, 239-248. [CrossRef]

46. Kleemann, F.; Lederer, J.; Aschenbrenner, P.; Rechberger, H.; Fellner, J. A method for determining buildings material composition prior to demolition. Build. Res. Inf. 2016, 44, 51-62. [CrossRef]

47. Mata, É.; Sasic Kalagasidis, A.; Johnsson, F.; Mata, E.; Kalagasidis, A.S.; Johnsson, F. Building-stock aggregation through archetype buildings: France, Germany, Spain and the UK. Build. Environ. 2014, 81, 270-282. [CrossRef]

48. Cerezo, C.; Sokol, J.; Reinhart, C.; Al-Mumin, A. Three Methods for Characterizing Building Archetypes in Urban Energy Simulation. A Case Study in Kuwait City. 2015. Available online: http://web.mit.edu/SustainableDesignLab/publications/BS2 015_KuwaitModel.pdf (accessed on 11 January 2019).

49. Sousa, C.; Cerezo, C.; Pina, A.; Ferrão, P. A Method for the Generation of Multi-Detail Building Archetype Definitions: Application to the City of Lisbon. 2015. Available online: https://infoscience.epfl.ch/record/213443/files/9_SOUSA.pdf (accessed on 11 January 2019).

50. Loga, T.; Stein, B.; Diefenbach, N. TABULA building typologies in 20 European countries-Making energy-related features of residential building stocks comparable. Energy Build. 2016, 132, 4-12. [CrossRef]

51. Mastrucci, A.; Marvuglia, A.; Leopold, U.; Benetto, E. Life Cycle Assessment of building stocks from urban to transnational scales: A review. Renew. Sustain. Energy Rev. 2017, 74, 316-332. [CrossRef]

52. Volk, R.; Stengel, J.; Schultmann, F. Building Information Modeling (BIM) for existing buildings-Literature review and future needs. Autom. Constr. 2014, 38, 109-127. [CrossRef]

53. Rose, C.M.; Stegemann, J.A. Characterising existing buildings as material banks (E-BAMB) to enable component reuse. Proc. Inst. Civ. Eng. Eng. Sustain. 2018, 172, 129-140. [CrossRef]

54. Copeland, S.; Bilec, M. Buildings as material banks using RFID and building information modeling in a circular economy. Procedia CIRP 2020, 90, 143-147. [CrossRef]

55. Cheng, J.C.P.; Ma, L.Y.H. A BIM-based system for demolition and renovation waste estimation and planning. Waste Manag. 2013, 33, 1539-1551. [CrossRef]

56. Su, S.; Li, S.; Ju, J.; Wang, Q.; Xu, Z. A building information modeling-based tool for estimating building demolition waste and evaluating its environmental impacts. Waste Manag. 2021, 134, 159-169. [CrossRef]

57. Kim, Y.C.; Hong, W.H.; Park, J.W.; Cha, G.W. An estimation framework for building information modeling (BIM)-based demolition waste by type. Waste Manag. Res. 2017, 35, 1285-1295. [CrossRef] [PubMed]

58. Augiseau, V.; Barles, S. Bilan de Flux de Matières de la Région Ile-de-France en 2015. Available online: https://www.researchgate. net/publication/346604865_Bilan_de_flux_de_matieres_de_la_region_Ile-de-France_en_2015 (accessed on 8 February 2021).

59. Augiseau, V. La Dimension Matérielle de l'urbanisation—Flux et Stocks de Matériaux de Construction en Ile-de-France, Université Paris 1 Panthéon-Sorbonne. 2017. Available online: http:/ / www.theses.fr/2017PA01H111 (accessed on 11 January 2019).

60. Augiseau, V. Construction materials flows and stocks in Paris region: An overview. Ecocycles 2020, 6, 18-22. [CrossRef] 
61. Augiseau, V.; Kim, E. Inflows and Outflows from Material Stocks of Buildings and Networks and their Space-Differentiated Drivers: The Case Study of the Paris Region. Sustainability 2021, 13, 1376. [CrossRef]

62. Mastrucci, A.; Marvuglia, A.; Popovici, E.; Leopold, U.; Benetto, E. Geospatial characterization of building material stocks for the life cycle assessment of end-of-life scenarios at the urban scale. Resour. Conserv. Recycl. 2017, 123, 54-66. [CrossRef]

63. Cerema. Les Fichiers Fonciers, Données Foncières Pour l'Aménagement. Available online: https://datafoncier.cerema.fr/ donnees / fichiers-fonciers (accessed on 4 August 2021).

64. IGN BD TOPO ${ }^{\circledR} \mid$ Géoservices. La Modélisation 2D et 3D du Territoire et de ses Infrastructures sur l'Ensemble du Territoire Français. Available online: https://geoservices.ign.fr/bdtopo (accessed on 4 August 2021).

65. ADEME. Diagnostics de Performance Energétique pour les Logements par Habitation. Available online: https://data.ademe.fr/ datasets / dpe-france (accessed on 4 August 2021).

66. Mailhac, A. Contribution au Développement d'une Méthodologie D'évaluation Environnementale aux Echelles Urbaines, Université de Toulouse. 2019. Available online: https://tel.archives-ouvertes.fr/tel-02889301/ (accessed on 12 October 2019).

67. European Commission. Directive 2008/98/EC of the European Parliament and of the Council. Available online: https://eur-lex. europa.eu/eli/dir/2008/98/oj (accessed on 19 August 2021).

68. European Commission. Commission Notice on Technical Guidance on the Classification of Waste C/2018/1447. Available online: https:/ / eur-lex.europa.eu/legal-content/EN/TXT/?uri=uriserv:OJ.C_.2018.124.01.0001.01.ENG\&toc=OJ:C:2018:124:TOC (accessed on 19 August 2021).

69. European Commission. Commission Decision 2000/532/EC of 3 May 2000 (European Waste Catalog). Available online: https: / / eur-lex.europa.eu/legal-content/EN/ ALL/?uri=celex\%3A32000D0532 (accessed on 19 August 2021).

70. Ministère de l’Ecologie. Décret N²011-610 du 31 mai 2011 Relatif au Diagnostic Portant sur la Gestion des Déchets Issus de la Démolition de Catégories de Bâtiments. 2011. Available online: https://www.legifrance.gouv.fr/loda/id/JORFTEXT000024099 263/ (accessed on 19 August 2021).

71. Ministère Chargé de la Construction. Formulaire de Récolement Relatif au Diagnostic Portant sur la Gestion des Déchets Issus de la Démolition; France. 2011. Available online: https:/ / www.formulaires.service-public.fr/gf/cerfa_14498.do (accessed on 24 March 2021).

72. Ministère de la Transition Ecologique. Stratégie Nationale Bas-Carbone (SNBC). Available online: https://www.ecologie.gouv.fr/ strategie-nationale-bas-carbone-snbc (accessed on 12 August 2021).

73. Traisnel, J.; Maïzia, M.; Roditi, D. Habitat et développement durable: Les perspectives offertes par le solaire thermique. Les Cah CLIP 2004, 16, 3-46.

74. Ministère de la Transition Ecologique. La Base de Données Sitadel2: Méthodologie I Données et Etudes Statistiques. Available online: https: / / www.statistiques.developpement-durable.gouv.fr/la-base-de-donnees-sitadel2-methodologie (accessed on 19 August 2021).

75. ADEME. l'Exercice de Prospective de l'Adème: Vision 2030-2050. 2012. Available online: https://www.ademe.fr/sites/default/ files /assets / documents/85536_vision_2030-2050_document_technique.pdf (accessed on 19 August 2021).

76. Institut d'Aménagement et d'Urbanisme_Ile-de-France. Éclairage sur la Rénovation Energétique du Bâti. 2018. Available online: https:/ / www.institutparisregion.fr/fileadmin/NewEtudes/Etude_1765/EclairageRenovEnergetiquePREE_mai2018_ CordeauSpadaro.pdf (accessed on 19 August 2021).

77. Horvitz, D.G.; Thompson, D.J. A Generalization of Sampling without Replacement from a Finite Universe. J. Am. Stat. Assoc. 1952, 47, 663-685. [CrossRef]

78. Brown, G.P. Billingsley, Probability and measure (Wiley, 1979), pp. 532,£ 28. 95. Proc. Edinb. Math. Soc. 1983, 26, 398-399. [CrossRef]

79. Barles, S. Urban metabolism of Paris and its region. J. Ind. Ecol. 2009, 13, 898-913. [CrossRef]

80. Insee. Estimation de la Population au 1er Janvier 2021. Available online: https://www.insee.fr/fr/statistiques/1893198 (accessed on 18 May 2021).

81. Insee. Définition-Unité Statistique. Available online: https://www.insee.fr/en/metadonnees/definition/c1528 (accessed on 22 June 2020).

82. Région Île-de-France. Plan Régional de Prévention et de Gestion des Déchets (PRPGD). 2019. Available online: https://www. iledefrance.fr/espace-media/divers/PRPGPD/CHAPITRE-II.pdf (accessed on 18 May 2021).

83. DRIEA. Documents d'Urbanisme et de Planification Sectorielle en Vigueur sur le Territoire Parisien. 2020. Available online: http:/ / www.driea.ile-de-france.developpement-durable.gouv.fr/IMG/pdf/200206-schema_documents_en_vigueur_sur_ le_territoire_parisien_janvier_2020_.pdf (accessed on 21 June 2020).

84. Augiseau, V.; Kim, E. Spatial characterization of construction material stocks: The case of the Paris region. Resour. Conserv. Recycl. 2021, 170, 105512. [CrossRef]

85. Direction Régionale de l'Equipement d'Ile-de-France. Déchets du BTP: Plan de Gestion Pour Paris et la Petite Couronne. 2004. Available online: http:/ / www.driea.ile-de-france.developpement-durable.gouv.fr/IMG/pdf/planppcpt_cle0ab4e8.pdf (accessed on 7 August 2020). 
86. Conseil Régional Ile de France. PREDEC-Plan Régional de Prévention et de Géstion des Déchets Issus des Chantiers du Bâtiment et des Travaux Publics. 2015. Available online: https://www.iledefrance.fr/sites/default/files/medias/2019/05/ predec_adopte2015.pdf (accessed on 13 July 2020).

87. Rouvreau, L.; Michel, P.; Serrand, M.; Montfort Climent, D.; Jayr, E. Projet ANR ASURET Analyse de Flux de Matière du Secteur de la Construction à l'Echelle de l'Ouvrage et du Territoire; BRGM: Orléans, France, 2012; p. 132. Available online: http://infoterre.brgm. $\mathrm{fr} /$ rapports / RP-61849-FR.pdf (accessed on 26 January 2019).

88. Liu, Q.; Cao, Z.; Liu, X.; Liu, L.; Dai, T.; Han, J.; Duan, H.; Wang, C.; Wang, H.; Liu, J.; et al. Product and Metal Stocks Accumulation of China's Megacities: Patterns, Drivers, and Implications. Environ. Sci. Technol. 2019, 53, 4128-4139. [CrossRef] [PubMed]

89. POUGET. Consultants Analyse Détaillée du parc Résidentiel Existant. 2017. Available online: https://www.programmepacte.fr/ sites/default/files/pdf/ranalyseparcresidentielexistantneufrenojuil17073web.pdf (accessed on 5 August 2019).

90. APUR. Les Habitations à bon Marché (HBM) de la Ceinture de Paris: Étude Historique. 2017. Available online: https://www.apur.org/sites/default/files/documents/publication/documents-associes/habitations_bon_marche_ceinture_ paris_historique.pdf?token=Mu_3L2OA (accessed on 5 August 2019).

91. APUR. Réhabilitation des Bâtiments Construits à Paris Entre 1945 et 1974_Pratiques Actuelles, Nouveaux Enjeux. 2016. Available online: https://www.apur.org/sites/default/files/documents/publication/documents-associes/rehabilitation_batiments_ annees_60.pdf?token=77hWYW_L (accessed on 5 August 2019).

92. POUGET Consultants. ADEME Bâtiments Résidentiels: Typologie du Parc Existant et Solutions Exemplaires Pour la Rénovation Energétique en France. 2015. Available online: https://episcope.eu/fileadmin/tabula/public/docs/brochure/FR_TABULA_ TypologyBrochure_Pouget.pdf (accessed on 5 August 2019).

93. Ecole Nationale des Travaux Publics de l'Etat (ENTPE); Centre d'études Techniques de l'équipement (CETE); Maisons Paysannes de France (MPF), Cerema; Institut des Sciences Appliquées (INSA) de Strasbourg. BATAN: Modélisation du Comportement Thermique du Bâtiment Ancien Avant 1948. 2011. Available online: https://www.rehabilitation-bati-ancien.fr/sites/creba/files/ fichiers/2021/09/006_BATAN_ENTPE_CETE_Est_et_Ouest.pdf (accessed on 5 August 2019).

94. Agence Nationale de l'Habitat (ANAH); PACT; SOCOTEC. Les Copropriétés des Années 50 à 80: Un Parc à Enjeux. 2011. Available online: www.businessimmo.com/etudes/29132/les-coproprietes-des-annees-50-a-80-un-parc-a-enjeux (accessed on 5 August 2019).

95. Energies et Avenir. Energies Demain Rénovation Energétique des Logements en Collectif à Chauffage Collectif: Performance et Potentiel des Systèmes de Chauffage à eau Chaude. 2011. Available online: https:/ /www.effinergie.org/web/images/attach/ base_doc/1405/EA_renov-batimentsFINAL.pdf (accessed on 5 August 2019).

96. APUR. Analyse de la Performance Thermique des Logements Parisiens. 2011. Available online: https://www.apur.org/fr/nostravaux/analyse-performance-thermique-logements-parisiens (accessed on 5 August 2019).

97. Tribu Energie; Maisons Paysannes de France (MPF). ENRABF, Concilier Economies D'énergie et Patrimoine. 2010. Available online: http:/ / www.rehabilitation-bati-ancien.fr/fr/espace-documentaire/enrabf-concilier-economies-denergie-et-patrimoine (accessed on 5 August 2019).

98. Centre d'Etudes Techniques de l'Equipement (CETE) de l'Es; Ecole Nationale des Travaux Publics de l'Etat (ENTPE); Maisons Paysannes de France (MPF). Connaissance des Bâtiments Anciens et Economies d’Energie. 2007. Available online: https://www. rehabilitation-bati-ancien.fr/sites/creba/files/fichiers/2021/09/039_Connaissance_bati_ancien_CETE_Est.pdf (accessed on 6 August 2019).

99. Graulière, P. Typologie des Bâtiments d'Habitation en France. Synthèse des Caractéristiques des Bâtiments D'habitation Existants Permettant l'Evaluation du Potentiel d'Amélioration Energétique; Ministère de l’Ecologie, de l'Energie, du Développement Durable et de la Mer: Paris, France, 2007.

100. Chemillier, P.; Buttenwieser, I.; Chevet, H. Panorama des Techniques du Bâtiment: 1947-1997; CSTB/Plan Construction et Architecture: Paris, France, 1997; Volume 335, ISBN 2-86891-272-9.

101. Chiffard, J.-F. Typologie Opérationnelle de l'Habitat Ancien: 1850-1948; Volue 1 de Actes de Colloques; Plan Construction: Montreuil, France, 1976. 